\title{
PROJECT PORTFOLIO SELECTION PROBLEMS: A REVIEW OF MODELS, UNCERTAINTY APPROACHES, SOLUTION TECHNIQUES, AND CASE STUDIES
}

\author{
Vahid MOHAGHEGHI ${ }^{1}$, Seyed Meysam MOUSAVI ${ }^{1 *}$, \\ Jurgita ANTUCHEVIČIENE் (12) Mohammad MOJTAHEDI ${ }^{3}$ \\ ${ }^{1}$ Department of Industrial Engineering, Shahed University, Tehran, Iran \\ ${ }^{2}$ Department of Construction Management and Real Estate, Faculty of Civil Engineering, \\ Vilnius Gediminas Technical University, Lithuania \\ ${ }^{3}$ Faculty of Built Environment, Kensington Campus, The University of New South Wales, \\ Sydney, Australia
}

Received 03 April 2019; accepted 22 September 2019

\begin{abstract}
Project portfolio selection has been the focus of many scholars in the last two decades. The number of studies on the strategic process has significantly increased over the past decade. Despite this increasing trend, previous studies have not been yet critically evaluated. This paper, therefore, aims to presents a comprehensive review of project portfolio selection and optimization studies focusing on the evaluation criteria, selection approach, solution approach, uncertainty modeling, and applications. This study reviews more than 140 papers on project portfolio selection research topic to identify the gaps and to present future trends. The findings show that not only the financial criteria but also social and environmental aspects of project portfolios have been focused by researchers in project portfolio selection in recent years. In addition, meta-heuristics and heuristics approach to finding the solution of mathematical models have been the critical research by scholars. Expert systems, artificial intelligence, and big data science have not been considered in project portfolio selection in the previous studies. In future, researchers can investigate the role of sustainability, resiliency, foreign investment, and exchange rates in project portfolio selection studies, and they can focus on artificial intelligence environments using big data and fuzzy stochastic optimization techniques.
\end{abstract}

Keywords: project portfolio selection, uncertainty approach, solution approach, selection approach, evaluation criteria, case studies.

JEL Classification: C00, C52, D70, D81, G11, O22.

*Corresponding author. E-mail:sm.mousavi@shahed.ac.ir

This is an Open Access article distributed under the terms of the Creative Commons Attribution License (http://creativecommons. org/licenses/by/4.0/), which permits unrestricted use, distribution, and reproduction in any medium, provided the original author and source are credited. 


\section{Introduction}

A portfolio consists of various components such as projects, programs, portfolios, and other tasks like maintenance and ongoing operations. All the components are grouped in order to ease the management of the work so that the strategic business objectives could be reached effectively. The projects or programs of a portfolio are not necessarily interdependent or directly related. In other words, it can be stated that they are normally unrelated. On the other hand, the components could share a common resources pool or even compete for funding (Project Management Institute [PMI], 2008). To put differently, a set of projects that share and compete for limited resources forms a portfolio of projects. A portfolio is directed under the sponsorship of a particular organization (Archer \& Ghasemzadeh, 1999).

Firm managers should select portfolios of projects to invest to achieve objectives. Project portfolio selection (PPS) is known as a periodic and continuous effort that involves selecting and funding portfolios of projects that are supporting organizations stated goals and objectives. An important aspect of this decision-making process is considering resources and other constraints (Schniederjans \& Santhanam, 1993; Killen \& Hunt, 2013). In other words, one of the most important reasons for PPS is the fact that the accumulated funding that all the candidate projects need highly exceeds the available investment resources (Mohagheghi, Mousavi, \& Vahdani, 2016; Mohagheghi, Mousavi, Aghamohagheghi, \& Vahdani, 2017a; Mohagheghi, Mousavi, Vahdani, \& Shahriari, 2017b).

PPS has been an interesting point of many scholars in the last 4 decades. It is very practical in areas such as new product development (NPD) and research and development $(\mathrm{R} \& \mathrm{D})$. Moreover, PPS is applicable in technology selection problems and similar topics (Iamratanakul and Patanakul, 2008; Mohagheghi, Mousavi, \& Vahdani, 2015b).

Project portfolio selection background: PPS has been studied by many scholars in the last two decades. Due to the importance of research and development (R\&D) projects, a large portion of studies was mainly concerned with R\&D projects. One of the first studies of PPS was carried out by Chu, Hsu, and Fehling (1996). They developed a Decision Support System (DSS) for R\&D project portfolio selection. However, most of the scholars refer to the initial work of Archer and Ghasemzadeh $(1998,1999)$ as the turning point of PPS studies. Their pioneer study (Archer \& Ghasemzadeh, 1998) introduced a DSS that used a novel framework for PPS with six operational stages. Later Archer and Ghasemzadeh (1999) developed their framework. Figure 1 shows a project portfolio selection framework introduced by Archer and Ghasemzadeh (1999).

Project portfolio selection research objectives: The main goal of PPS is to form an optimal portfolio of projects that simultaneously achieves the company's strategic objectives and considers the limitations that are imposed on the process. Moreover, controlling the risk and the performance objectives are some of the other goals that should be considered (Better \& Glover, 2006; Ebrahimnejad, Mousavi, Tavakkoli-Moghaddam, Hashemi, \& Vahdani 2012).

PPS studies have developed over the years. In the initial studies, financial criteria of projects formed the main focus. Later, frameworks were developed to attend to PPS with an emphasis on strategic criteria. Recently, there has been scattered focus on other criteria such as sustainable development, strategic alliance, the risk of investment and organizational readiness (Khalili-Damghani \& Sadi-Nezhad, 2013a). The following presents some of the main objectives of PPS: 


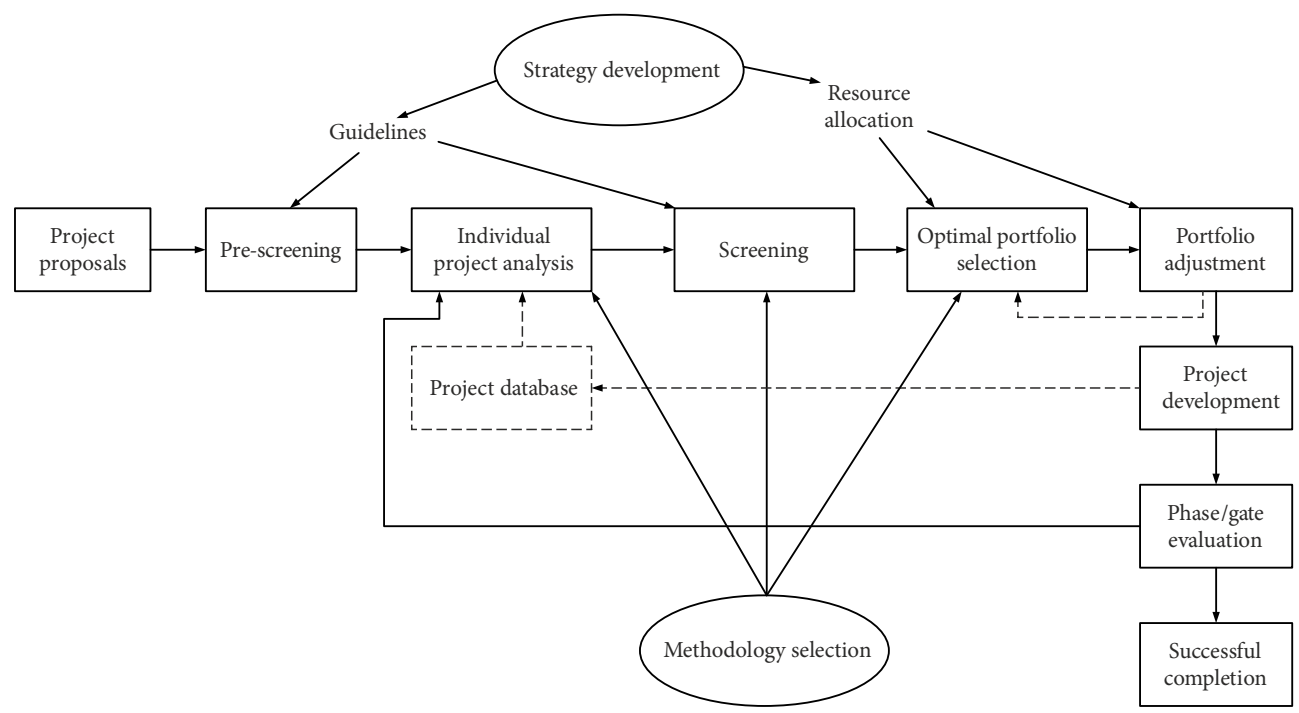

Figure 1. Project portfolio selection framework (Archer \& Ghasemzadeh, 1999)

- Maximizing financial conditions with indexes like net present value (NPV), return on investment (ROR), etc.;

- Maximizing non-financial benefits;

- Cost reduction;

- Risk control;

- Optimizing scheduling of activities;

- Optimizing allocation of resources;

- Handling uncertainty and vagueness.

The significance of project portfolio selection research: Researchers have not treated PPS in much detail before 2000s that the number of studies on PPS had been very low. In fact, unlike project selection studies or portfolio selection studies, PPS studies became increasingly popular since the early 2000s. Studies of Archer and Ghasemzadeh $(1998,1999)$ paved the way and created a new path for scholars to conduct research on PPS.

In the next following decade (the 2000s), the number of studies on PPS increased slowly but stayed at a low level. However, in recent years (the 2010s), the number of studies on PPS has dramatically increased. To further illustrate the trend of PPS studies, the term "project portfolio selection" was searched in SCOPUS on 31st May 2019. The results are presented as follows:

The number of documents by year is shown in Figure 2. This figure perfectly presents the increasing trend of PPS studies.

Table 1 presents the results of searching on SCOPUS. Some of the main results are as follows:

- In total, 259 papers were discovered.

- Growing trend of this topic in recent years can be observed.

- $91.8 \%$ of the sources belong to the group of conference papers and journal articles. This implies that most researchers are attracted to project portfolio studies. 


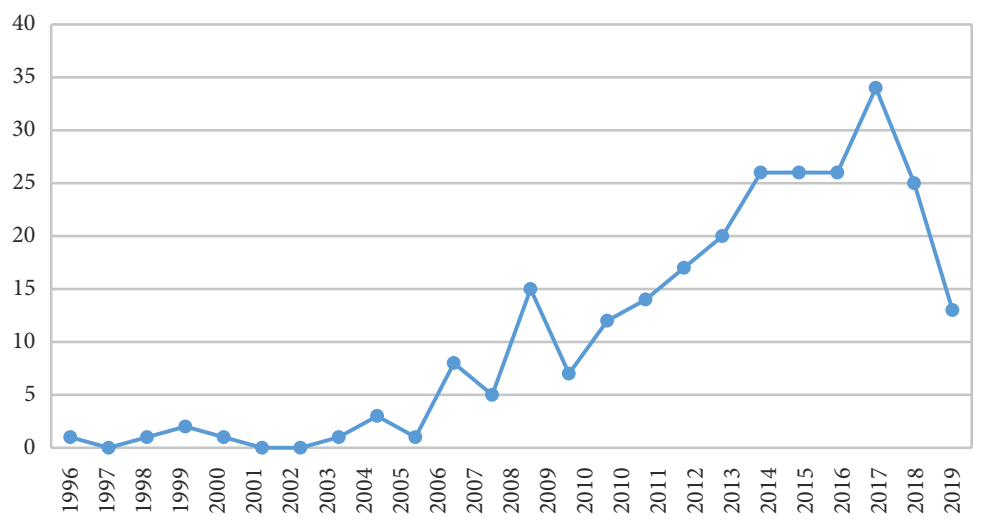

Figure 2. Trend of PPS studies between 1996 to 2019

Table 1. A statistical report from SCOPUS to PPS

\begin{tabular}{|c|c|c|c|c|}
\hline Source title & Author name & Year & Document type & Subject area \\
\hline $\begin{array}{l}\text { European journal of } \\
\text { operation research (10) }\end{array}$ & Gutjahr, W. J. (9) & $2019(13)$ & Article (162) & $\begin{array}{l}\text { Computer Science } \\
(118)\end{array}$ \\
\hline $\begin{array}{l}\text { Studies in computational } \\
\text { intelligence (10) }\end{array}$ & Cruz-Reyes, L. (9) & $2018(25)$ & $\begin{array}{l}\text { Conference } \\
\text { paper }(76)\end{array}$ & Engineering (106) \\
\hline $\begin{array}{l}\text { Annals of operation } \\
\text { research (5) }\end{array}$ & Li, X (8) & $2017(34)$ & $\begin{array}{l}\text { Book chapter } \\
(10)\end{array}$ & Decision Sciences (72) \\
\hline $\begin{array}{l}\text { Journal of the operational } \\
\text { research society (5) }\end{array}$ & Tavana, M. (8) & $2016(26)$ & Review (4) & $\begin{array}{l}\text { Business, management } \\
\text { and accounting (62) }\end{array}$ \\
\hline $\begin{array}{l}\text { Expert systems with } \\
\text { applications (4) }\end{array}$ & Fernandez, E. (7) & $2015(26)$ & $\begin{array}{l}\text { Conference } \\
\text { review (4) }\end{array}$ & Mathematics (53) \\
\hline $\begin{array}{l}\text { Advances in intelligent } \\
\text { systems and computing (3) }\end{array}$ & Liesiö, J. (7) & $2014(26)$ & $\begin{array}{l}\text { Article in press } \\
\text { (3) }\end{array}$ & Social Sciences (14) \\
\hline Information sciences (3) & Mohagheghi, V. (6) & $2013(20)$ & & $\begin{array}{l}\text { Environmental } \\
\text { sciences (12) }\end{array}$ \\
\hline Sustainability (3) & Mousavi, S. M. (6) & $2012(17)$ & & $\begin{array}{l}\text { Economics, } \\
\text { econometrics and } \\
\text { finance }(11)\end{array}$ \\
\hline $\begin{array}{l}\text { Applied mechanics and } \\
\text { materials (2) }\end{array}$ & $\begin{array}{l}\text { Khalili- } \\
\text { Damghani, K. (6) }\end{array}$ & $2011(14)$ & & Energy (7) \\
\hline Applied soft computing (2) & Salo, A. (5) & $2010(12)$ & & $\begin{array}{l}\text { Earth and planetary } \\
\text { sciences (7) }\end{array}$ \\
\hline $\begin{array}{l}\text { Arabian journal for science } \\
\text { and engineering (2) }\end{array}$ & Carazo, A. F. (5) & $2009(8)$ & & Psychology (5) \\
\hline $\begin{array}{l}\text { Computers and Industrial } \\
\text { Engineering (2) }\end{array}$ & & $2008(15)$ & & Multidisciplinary (3) \\
\hline $\begin{array}{l}\text { Computers and operations } \\
\text { research (2) }\end{array}$ & & $2007(5)$ & & $\begin{array}{l}\text { Agricultural and } \\
\text { Biological sciences (3) }\end{array}$ \\
\hline \multirow[t]{2}{*}{ Decision analysis (2) } & & $2006(8)$ & & \\
\hline & & $2005(1)$ & & \\
\hline
\end{tabular}


The best journal sources of PPS are presented as follows:

- European Journal of Operation Research (10);

- Annals of Operation Research (5);

- Journal of Operational Research Society (5);

- Expert Systems with Applications (4);

- Information Sciences (3);

- Sustainability (3).

When it comes to analyzing subject area, it can be observed that the topic is investigated mostly in areas of engineering, computer science, decision science, business, management and accounting, mathematics, social sciences, environmental sciences, and energy, respectively.

The rest of this paper is organized as follows: the method and base for the review in this paper are presented in the next section. In section 2, various factors and criteria involved in PPS decision-making are reviewed. Due to the uncertain project environment, section 3 reviews different approaches to uncertainty modeling tools. Modeling and selection approaches are reviewed in section 4 . Section 5 presents a review of solutions approaches of PPS. Due to the importance of this decision-making process in a real-world application, a review of applications and real-life case studies is presented in section 6. Finally, further research directions for both academic and practitioners and concluding remarks are addressed in last Section.

\section{Describing the method and base for the literature review}

This paper presents a wider literature review at the intersection of project management and project portfolio optimization. A structured keyword search was applied to databases and major publisher websites to identify related papers for this review. Keywords such as "optimization", "selection", "evaluation", "mathematical modeling" were combined with project-related words such as "project portfolio", "project management", "construction project", "research and development" and "new product development". The papers were applied in a research method in which different categories like selection and evaluation criteria, uncertainty, modeling and scoring approaches, solution approaches and applications, and case studies were identified. In addition, all the papers which met the above criteria between 1993 and 2018 were extracted from Scopus or Web of Science. The technique for data collection and for the review is similar to approaches applied by Seuring and Muller (2008) and Seuring (2013). Figure 3 presents the study flowchart for the identification, screening, eligibility, and included articles. The taxonomy of the applied literature review method is depicted in Figure 4.

In this study, the literature search is used for material collection. In the review section, after setting the criteria and the categories for review, the literature was reviewed on the basis of the identified topics. This has led to a presentation of the survey for each section.

The terminologies applied in this paper such as "project portfolio", "project portfolio selection", "sustainable", "uncertainty", etc. are described in the context of this paper.

Criteria applied in content analysis: Two main categories of deductive and inductive approaches are often employed to form criteria for content analysis. Given the fact that to the best of our knowledge, comprehensive reviews on PPS did not exist, this paper has employed a deductive approach based on the existing studies on similar subjects to obtain review criteria. The following aspects will be discussed: 
- The selection and evaluation criteria such as financial, risk, strategic, green, social, sustainable, etc. are evaluated. The assessment contains in Tables 2 to 9 in which the papers applying various approaches to the studied criteria are categorized. Then, a brief critical analysis of the previous research based on the selected criteria is presented to evaluate the existing research and to find the potential gaps for further investigation.

- Given the uncertain environment of projects, uncertainty is discussed in a separate section (Section 4). Different approaches to modeling and expressing uncertainty which have been applied in the literature are reviewed. This review contains an analysis of papers based on stochastic, fuzzy, grey, and uncertain theory tools.

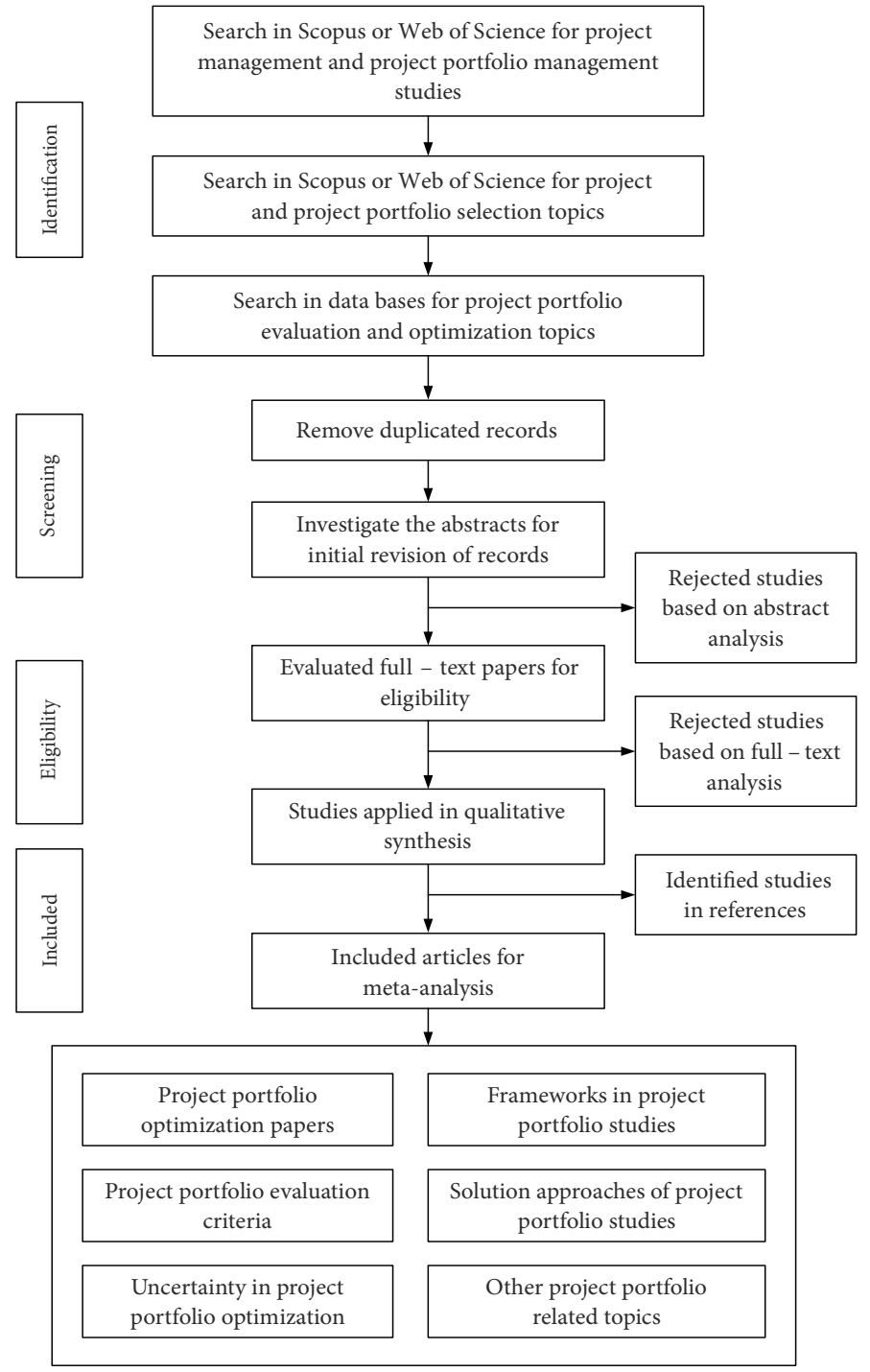

Figure 3. The study flowchart for the identification, screening, eligibility and included of articles 
- The modeling approach applied to PPS is reviewed in Section 5. Given the fact that there was no clear starting point, the categories were established based on an inductive approach. The main identified categories are frameworks and DSSs, optimizing and scoring methods. Frameworks and DSSs form a more general approach that could include optimizing and scoring methods. However, given their importance in the application, they are first reviewed and then optimizing and scoring methods are discussed.

- Solution approaches are categorized by following the main groups mentioned in optimization literature reviews in Section 6. Therefore, two main categories of exact and heuristics and meta-heuristics solutions approaches are formed, and the papers are reviewed accordingly.

- Given the fact that PPS is highly applicable in real-life problems, a separate section (Section 7) is presented to mention the applied cases of PPS. The aim of this section is to offer the areas in which PPS studies have been carried out.

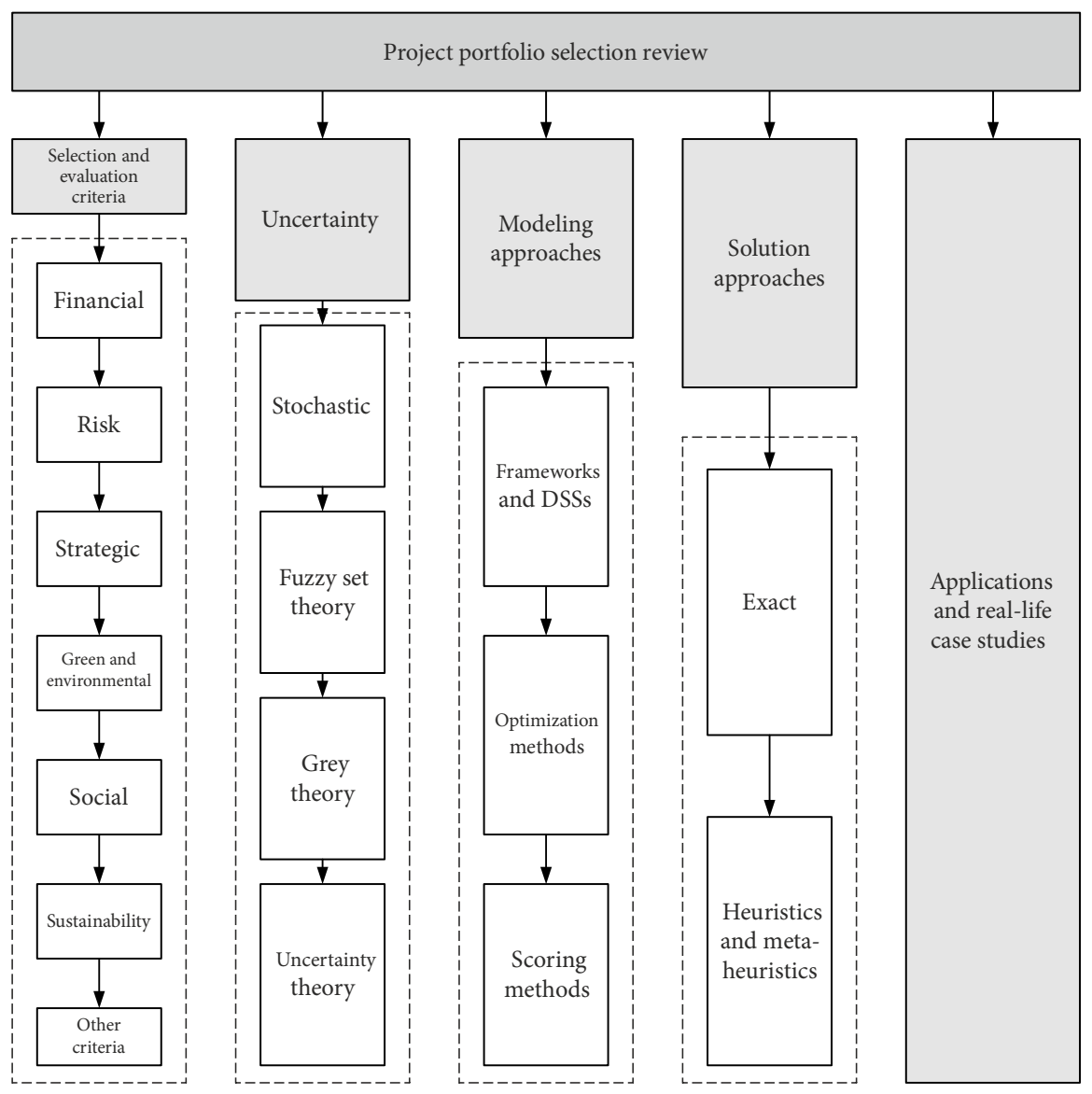

Figure 4. Taxonomy of the literature review 


\section{Selection and evaluation criteria}

In this section, the criteria which have been utilized in PPS problems by scholars in previous research between 1993 and 2018 are identified and categorized. In single-objective approaches often cost was referred to as the selection and evaluation criteria. However, since this problem affects various parts of an organization, often multi-criteria decision-making approaches are employed, and multiple conflicting criteria are addressed. The objective of this section is to give a review on various criteria applied in PPS problems.

\subsection{Financial}

Financial aspect was one of the first criterion that was investigated in PPS problems. Various ways have been tried to assess financial impacts of projects and project portfolios. Some of the applied criteria of financial assessments are net present value (NPV), financial return, and return on investment (ROI). Table 2 gives a summary of some of the research using financial assessment methods.

It can be observed that using NPV is one of the most common approaches in considering financial criteria in PPS. One of the trends in using NPV is simultaneously considering NPV and some measures of financial risk. Using variance and semi-variance of NPV in addition to NPV is one of the trends in financial assessment of PP. However, using NPV has its drawbacks. The main issue with applying NPV is that uncertainty profoundly influences this index and given the fact that at the initial phases of projects high degrees of uncertainty exist, the results would lose their reliability. One solution is to increase the level of knowledge by using experienced experts or using historical data from similar projects. Another solution could be using proper tools to model uncertainty.

Table 2. Papers using financial criteria

\begin{tabular}{|l|l|}
\hline \multicolumn{1}{|c|}{ Researcher } & \multicolumn{1}{c|}{ Criteria } \\
\hline Carlsson, Fullér, Heikkilä, and Majlender (2007) & Fuzzy return on investment \\
\hline Hu, Wang, Fetch, and Bidanda (2008) & Cost minimizing \\
\hline $\begin{array}{l}\text { Gutjahr, Katzensteiner, Reiter Stummer, and Denk (2008), Gutjahr } \\
\text { and Reiter (2010), Doerner, Gutjahr, Hartl, Strauss, and Stummer } \\
\text { (2006), Bhattacharyya, Chatterjee, and Kar (2010) }\end{array}$ & $\begin{array}{l}\text { Economic and Financial } \\
\text { benefits }\end{array}$ \\
\hline Wang and Chen (2011) & Net return \\
\hline $\begin{array}{l}\text { Li, Qin, and Cheng (2014), Qin, J. Li, and L. Li (2014), Carlsson } \\
\text { et al. (2007) }\end{array}$ & Fuzzy net present value \\
\hline Khalili-Damghani and Tavana (2014) & Investment \\
\hline $\begin{array}{l}\text { Mohagheghi et al. (2015b), Mohagheghi et al. (2016), Mohagheghi } \\
\text { et al. (2017a), Xu, Liu, Li, and Luo (2017), Zhang, Mei, Lu, } \\
\text { and Xiao (2011) }\end{array}$ & $\begin{array}{l}\text { The ratio of FNPV to lower } \\
\text { semi-variance }\end{array}$ \\
\hline $\begin{array}{l}\text { Conka, Vayvay, and Sennaroglu (2008), Shou and Huang (2010), } \\
\text { Nikkhahnasab and Najafi (2013), Nowak (2013), Li et al. (2015), } \\
\text { Li, Fang, Guo, Deng, and Qi (2016), Safair, Méndez, Babat, } \\
\text { Medaglia, and Zuluaga (2017), Li, Zhong, Zhang, and Wang (2017) }\end{array}$ & Net present value \\
\hline Tavana, Shiraz, and Di Caprio (2019) & Maximum assets return \\
\hline
\end{tabular}




\subsection{Risk}

Risk is a vital topic in project portfolio management. Risk refers to a vague event or situation which, if it happens, makes major positive or negative impacts on at least one of the objectives of a project portfolio (PMI, 2008). Risks are manageable at the portfolio and project level. However, attending to risks at the portfolio level can enhance the effectiveness of the process (Aritua, Smith, \& Bower, 2009). PMI's Standard for Portfolio Management (2008) groups risks of portfolio in three main categories of structural, component, and overall risks. Structural risks mean the risks that are related to the formation of the group of projects in addition to the potential problems among the elements. The second group is component risks that are the risks which the project manager has to escalate to the portfolio level for information or action. Finally, the last group of risks is overall risk that attends to the interdependencies between projects. This is more than only the sum of risks associated with single projects (Olsson, 2008). The management of risks a very substantial element of project portfolio management. Risk management gives the organization the power to handle opportunities and threats (Teller \& Kock, 2013; Mousavi, Tavakkoli-Moghaddam, Azaron, Mojtahedi, \& Hashemi, 2011a; Mousavi, Tavakkoli-Moghaddam, Hashemi, \& Mojtahedi, 2011b). Finding the best portfolio of projects requires addressing projects' risks. In the literature, risk has been addressed from various perspectives. Risk of investment, risk of project implementation and risk of uncertainty are some of the aspects. Table 3 presents various aspects of risks addressed in project portfolio selection literature. One of the aspects of addressing risks at the portfolio level is considering downside risk (e.g., Zhang, et al., 2011; Mohagheghi et al., 2017a; Li, et al., 2017). This approach divides the impacts of risks on the portfolio in two main groups of positive and negative impacts. Then, the approach tries to minimize only the negative consequences. In other words, risks have both positive and negative impacts and minimizing both impacts would reduce the efficiency of the method (Ebrahimnejad, Mousavi, Tavakkoli-Moghaddam, \& Heydar, 2014; Hashemi, Mousavi, \& Mojtahedi, 2011; Hashemi, Mousavi, Tavakkoli-Moghaddam, \& Gholipour, 2013; Zolfaghari \& Mousavi, 2018).

Table 3. Various aspects of risk addressed in PPS literature

\begin{tabular}{|c|c|}
\hline Researcher & Risk Approach \\
\hline Ghaeli, Vavrik, and Nasvadi (2003) & $\begin{array}{l}\text { Technical, public acceptance, political acceptance, } \\
\text { customer risk addressed by AHP }\end{array}$ \\
\hline Gutjahr and Reiter (2010) & Risk of possibly overtime for subcontractors \\
\hline Bas (2012) & Risks regarding cash \\
\hline $\begin{array}{l}\text { Gutjahr and Froeschl (2013), Zhou, Huang, } \\
\text { Teng, and Zhao (2012) }\end{array}$ & Risk preference of decision makers \\
\hline $\begin{array}{l}\text { Khalili-Damghani, Sadi-Nezhad, Lotfi, and } \\
\text { Tavana (2013) }\end{array}$ & Risk of investment \\
\hline Mira et al. (2012) & Amount of risk that the project controls \\
\hline Abbasianjahromi and Rajaie (2012) & The risk endurable level of company (RELC) \\
\hline
\end{tabular}


End of Table 3

\begin{tabular}{|l|l|}
\hline \multicolumn{1}{|c|}{ Researcher } & \multicolumn{1}{c|}{ Risk Approach } \\
\hline $\begin{array}{l}\text { Li, Cao, S. Li, Guo, and Zhao (2012), Rabbani, } \\
\text { Najjarbashi, and Joudi (2013), Gurgur (2009), } \\
\text { Bhattacharyya et al. (2010) }\end{array}$ & Risk of each project in mathematical modeling \\
\hline Li et al. (2014) & Conditional value at risk \\
\hline Hall, Long, Qi, and Sim (2015) & Underperformance Risk \\
\hline Gang et al. (2015) & $\begin{array}{l}\text { Expected risk of implementing project, } \\
\text { Minimization of Average Project Risk }\end{array}$ \\
\hline Jadda and Idrissi (2015) & Risk control \\
\hline $\begin{array}{l}\text { Mohagheghi et al. (2015b, 2017a), Zhang et al. } \\
\text { (2011) }\end{array}$ & A new risk index based on lower semi variance \\
\hline $\begin{array}{l}\text { Sefair et al. (2017), Kettunen and Salo (2017), } \\
\text { Mohagheghi et al. (2016), Xu et al. (2017), } \\
\text { Li et al. (2017) }\end{array}$ & $\begin{array}{l}\text { Downside risk measure, Mean-semivariance, } \\
\text { Lower semi variance, skewness risk, mean } \\
\text { variance }\end{array}$ \\
\hline Yan and Ji (2017) & Risk of Bankruptcy \\
\hline Tang, Zhou, and Cao (2017) & Investment risk tolerance \\
\hline
\end{tabular}

\subsection{Strategic criteria}

PPS is a strategic level problem. To put differently in this process, the aim is to achieve strategic goals through project implementation. As a result, it is necessary to attend to strategy and strategic criteria in PPS. This factor has been used from the initial studies to the recent ones. To present various forms of considering strategy in PPS studies, Table 4 is provided. Obviously, better offering the strategic criteria makes the studies closer to real-world conditions.

\subsection{Green and environmental}

Today's environmental condition has improved the necessity of considering green and environmental issues in different decision-making problems. When it comes to project evaluation, these issues become even more important. This is caused by the fact that projects have different environmental impacts that have to be regarded while making project-related decisions. Table 5 presents a review of various ways green and environmental criteria were applied in PPS.

\subsection{Social}

Social impacts of projects are taken in various PPS studies. For instance, a group of PPS studies mainly focuses on social PPS. These projects have different characteristics and therefore cannot be addressed by using financial approaches. Some of the studies concentrate on staff assignment and issue like learning in PPS (e.g. Gutjahr, Katzensteiner, Reiter, Stummer, \& Denk, 2010; Gutjahr \& Reiter, 2010). Table 6 gives a briefing of approaches applied in addressing social criteria in PPS. 
Table 4. Various forms of addressing strategy

\begin{tabular}{|l|l|}
\hline \multicolumn{1}{|c|}{ Researcher } & \multicolumn{1}{c|}{ Addressing Strategy } \\
\hline Chu et al. (1996) & Strategic selection algorithm \\
\hline Archer and Ghasemzadeh (1998, 1999) & $\begin{array}{l}\text { Strategy Development (determination of strategic } \\
\text { focus, using techniques such as strategic } \\
\text { Mapping, and setting resource constraints) }\end{array}$ \\
\hline Olundh and Ritzen (2004) & Strategic level decision making \\
\hline Carlsson et al. (2007) & Strategic fit \\
\hline Gutjahr et al. (2008) & $\begin{array}{l}\text { The strategic benefits accrued from the increments } \\
\text { of the efficiency values in objective function }\end{array}$ \\
\hline Stummer, Kiesling, and Gutjahr (2009) & Strategic weights of competencies in objective function \\
\hline Gutjahr and Reiter (2010) & Strategic gains in mathematical modeling \\
\hline Koppinen and Rosqvist (2010) & Asset strategy \\
\hline Wen (2010) & Strategy-oriented process model \\
\hline Zhang et al. (2011) & Optimal investment strategy \\
\hline Zhu and Wang (2012) & Strategic balance \\
\hline Abbasianjahromi and Rajaie (2012) & Strategic planning \\
\hline $\begin{array}{l}\text { Khalili-Damghani and Sadi-Nezhad } \\
\text { (2013a), Khalili-Damghani and Tavana } \\
\text { (2014) }\end{array}$ & Strategic framework \\
\hline $\begin{array}{l}\text { Kaiser, El Arbi, and Ahlemann (2015), } \\
\text { Lifshits and Avdoshin (2016) }\end{array}$ & Strategic response and goals \\
\hline Jeng and Huang (2015) & Strategy for differentiating products and services \\
\hline $\begin{array}{l}\text { Jadda and Idrissi (2015), Mohagheghi et al. } \\
\text { (2016), Khalili-Damghani and } \\
\text { Sadi-Nezhad (2013b }\end{array}$ & Strategic alignment \\
\hline $\begin{array}{l}\text { Wang and Song (2016), Ghassemi, and } \\
\text { Amalnick (2018), Jafarzadeh, Tareghian, } \\
\text { Rahbarnia, and Ghanbari (2015) }\end{array}$ & Reinvestment strategy \\
\hline
\end{tabular}

Table 5. Applying green and environmental criteria in PPS

\begin{tabular}{|l|l|}
\hline \multicolumn{1}{|c|}{ Researcher } & \multicolumn{1}{c|}{ Green and environmental approach } \\
\hline Olundh and Ritzen (2004) & Environmental aspects in product development \\
\hline Koppinen and Rosqvist (2010) & Environmental requirements in Infrastructure Sector \\
\hline $\begin{array}{l}\text { Khalili-Damghani et al. (2013), } \\
\text { Khalili-Damghani and Sadi-Nezhad } \\
\text { (2013a), Khalili-Damghani } \\
\text { and Tavana (2014) }\end{array}$ & Environmental analysis \\
\hline Mavrotas and Pechak (2013) & $\begin{array}{l}\text { Considering Clean Development Mechanism (CDM) } \\
\text { in PPS }\end{array}$ \\
\hline $\begin{array}{l}\text { Mohagheghi et al. (2015b), Mohagheghi } \\
\text { et al. (2016) }\end{array}$ & $\begin{array}{l}\text { Environmental impacts such as carbon emission } \\
\text { reduction and water pollution reduction }\end{array}$ \\
\hline Yang, Song, Huang, and Xia (2015) & Environmental protection \\
\hline $\begin{array}{l}\text { Tavana, Keramatpour, Santos-Arteaga, } \\
\text { and Ghorbaniane (2015) }\end{array}$ & Environment friendliness \\
\hline $\begin{array}{l}\text { Debnath, Roy, Kar, Zavadskas, and } \\
\text { Antucheviciene (2017) }\end{array}$ & Agro By-Products project portfolio selection \\
\hline
\end{tabular}


Table 6. Considering social aspects in PPS

\begin{tabular}{|l|l|}
\hline \multicolumn{1}{|c|}{ Researcher } & \multicolumn{1}{c|}{ Social approach } \\
\hline Gutjahr et al. (2010), Gutjahr and Reiter (2010) & Employee competencies and Staff assignment \\
\hline Koppinen and Rosqvist (2010) & $\begin{array}{l}\text { Staff issue and social changes in Infrastructure } \\
\text { Sector }\end{array}$ \\
\hline Shou and Huang (2010) & $\begin{array}{l}\text { Maximizing the overall social efficiency of the } \\
\text { market }\end{array}$ \\
\hline Wang and Shou (2011) & $\begin{array}{l}\text { Social objectives like maximizing social benefits } \\
\text { and customer satisfaction }\end{array}$ \\
\hline Khalili-Damghani et al. (2013) & $\begin{array}{l}\text { Social Effect (Direct social effect of a portfolio } \\
\text { of the project in a long-term period) }\end{array}$ \\
\hline $\begin{array}{l}\text { Fernandez, Lopez, Mazcorro, Olmedo, } \\
\text { and Coello (2013) }\end{array}$ & $\begin{array}{l}\text { Public project portfolio selection with highest } \\
\text { social returns }\end{array}$ \\
\hline Zaras, Marin, and Boudreau-Trude (2012) & Social, welfare and health \\
\hline Cruz-Reyes, Medina, and López (2013) & A DSS for social PPS \\
\hline Rivera et al. (2013) & Ant-Colony Outranking System for social PPS \\
\hline Khalili-Damghani and Sadi-Nezhad (2013a, b) & Social analysis \\
\hline $\begin{array}{l}\text { Cruz-Reyes, Trejo, Irrarragorri, and Santillán } \\
\text { (2014) }\end{array}$ & Argumentation theory in public PPS \\
\hline Khalili-Damghani and Tavana (2014) & $\begin{array}{l}\text { Social analysis such as the provision of } \\
\text { employment, health and safety, public acceptance }\end{array}$ \\
\hline $\begin{array}{l}\text { Mohagheghi et al. (2016), Schaeffer and } \\
\text { Cruz-Reyes (2016), Mohagheghi, Mousavi, } \\
\text { and Siadat (2015a) }\end{array}$ & Social impacts \\
\hline Lukovac, Pamučar, Popović, and Đorović (2017) & Analyzing human resources: \\
\hline
\end{tabular}

\subsection{Sustainability}

The concept of sustainability is based on the interrelationship among social, environmental and financial development. Sustainable development cannot be reached without adequate understanding of financial decisions impact on the society and the environment (Hutchins \& Sutherland, 2008). One example of application of sustainability is a sustainable market valuation of buildings (Zavadskas et al., 2017a). Sustainable project portfolio selection is a step towards organizational sustainable development. In recent years, a number of studies have employed the concept of sustainability in PPS. Table 7 presents these studies.

\subsection{Other criteria}

Since PPS is utilized in many areas, different criteria have been applied to get the optimal portfolio of projects. In other words, to find the best portfolio, it is necessary to identify criteria according to features of the application environment. Therefore, given the high applicability of this problem, it can be concluded that it is not possible to fully categorize all the criteria or groups of criteria used in PPS. However, to present other criteria that were applied in this problem, Table 8 provides a brief description of other criteria applied in PPS. One of the new trends in these studies that has made them closer to real-world conditions is 
Table 7. A review of papers addressing sustainability in PPS

\begin{tabular}{|l|l|}
\hline Researcher & Considering sustainability \\
\hline $\begin{array}{l}\text { Fouladgar, Yazdani-Chamzini, Yakhchali, } \\
\text { Ghasempourabadi, and Badri (2011) }\end{array}$ & Sustainability considered in VIKOR method \\
\hline $\begin{array}{l}\text { Khalili-Damghani and Sadi-Nezhad } \\
\text { (2013a, b), Khalili-Damghani and Tavana } \\
(2014)\end{array}$ & Sustainable strategic framework for PPS \\
\hline Zaras et al. (2012) & Sustainable development project selection \\
\hline Mohagheghi et al. (2015a) & Model of sustainable PPS in production environment \\
\hline Mohagheghi et al. (2016) & Sustainable project portfolio selection \\
\hline $\begin{array}{l}\text { Dobrovolskienė and Tamošiūnienė } \\
\text { (2016) }\end{array}$ & Sustainability-oriented financial resource allocation \\
\hline $\begin{array}{l}\text { Martins, López, de Almeida, Almeida, } \\
\text { and Bortoluzzi (2017) }\end{array}$ & $\begin{array}{l}\text { Sustainable strategic decision making in an electricity } \\
\text { company }\end{array}$ \\
\hline
\end{tabular}

Table 8. Some of the other criteria used in PPS

\begin{tabular}{|l|l|}
\hline \multicolumn{1}{|c|}{ Researcher } & \multicolumn{1}{c|}{ Criteria } \\
\hline Stummer and Kiesling (2009) & Monetary and nonmonetary criteria \\
\hline Koppinen and Rosqvist (2010) & $\begin{array}{l}\text { Value creation, Resource-availability, Flexibility } \\
\text { provided by the alternatives in case of future changes } \\
\text { (real options) }\end{array}$ \\
\hline Conka et al. (2008) & Technological \\
\hline Fouladgar et al. (2011) & payback period, flexibility \\
\hline Rivera et al. (2013) & Synergy \\
\hline Carazo (2015) & Interdependency, Synergies \\
\hline Tavana et al. (2015) & Opportunity, Technology \\
\hline Bhattacharyya (2015) & $\begin{array}{l}\text { Technical interdependency, resource interdependency, } \\
\text { project completion time }\end{array}$ \\
\hline Mohagheghi et al. (2016) & Organizational readiness, Non-financial benefits \\
\hline Hu and Szmerekovsky (2016) & Budget Allocation, Budget Slack \\
\hline Schaeffer and Cruz-Reyes (2016) & Balancing the portfolio \\
\hline Martínez-Vega et al. (2018) & Dynamic Allocation of Resources \\
\hline
\end{tabular}

addressing project interdependency and synergies. Projects, while selected together, can affect the level of required resources and efforts. On the other hand, they can affect the expected outcome while addressed together.

\section{Uncertainty}

In fact, in any real-world project selection process, two concepts increase the complexity of the process. One is the constraints and limitations imposed on the process, and the other one is the uncertainty that exists in the project evaluation (Mavrotas \& Pechak, 2013a, 2013b). In investment-related problems, experts often are handling insufficient data. Uncertainty has a vital impact on project management problems. Given the role of vagueness in project 
environment, this section gives a review of the uncertainty modeling tools applied in PPS literature. Three main categories of stochastic, fuzzy and grey in addition to the uncertainty theory introduced by Liu (2007) are reviewed.

\subsection{Stochastic uncertainty}

Using stochastic approaches is one of the methods applied in PPS. The stochastic theory is based on using historical data. Stochastic optimization covers a collection of tools applied to either minimize or maximize an objective function while dealing with randomness (Mousavi, Jolai, \& Tavakkoli-Moghaddam, 2013). In recent decades, such methods have proved themselves as vital tools for science, engineering, business, computer science, and statistics. Often there are two main ways for randomness to enter the problem: one is the cost function, and the other one is the constraint set (Hannah, 2015). Despite the high applicability of this approach in various areas, using it in a project environment is not very common. The main reason could be the fact that projects are unique and having historical data in projects in some cases is not even possible. However, in some projects, data from similar past projects could be used to overcome this shortcoming. In Table 9 a review of studies that have used stochastic tools to find the best portfolio of projects is presented.

Table 9. Reviewing studies with stochastic tools

\begin{tabular}{|l|l|}
\hline \multicolumn{1}{|c|}{ Researcher } & \multicolumn{1}{c|}{ Stochastic Approach } \\
\hline Graves, Ringuest, and Medaglia (2003) & Conditional stochastic dominance \\
\hline Gurgur (2009) & Stochastic programming \\
\hline Gutjahr and Reiter (2010) & Bi-objective stochastic optimization problem \\
\hline Mavrotas and Pechak (2013a, 2013b) & Stochastic parameters in Monte Carlo simulation \\
\hline Yang et al. (2015) & Stochastic Multi-criteria acceptability analysis \\
\hline Tofighian, Moezzi, Barfuei, and Shafiee (2018) & Stochastic income \\
\hline $\begin{array}{l}\text { Gutjahr and Froeschl (2013), Panadero et al. } \\
\text { (2018), Felberbauer, Gutjahr, and Doerner (2018) }\end{array}$ & Stochastic optimization \\
\hline Farshchian and Heravi (2018) & Stochastic agent-based simulation model \\
\hline
\end{tabular}

\subsection{Fuzzy sets theory}

In a project environment, vagueness in addition to the imprecision of information and lack of proper data make using experts' ideas inevitable. A proper tool in considering uncertainty is fuzzy sets theory. Many studies have utilized fuzzy sets theory to handle uncertainty in PPS (Ebrahimnejad et al., 2012; Mohagheghi, Mousavi, Vahdani, \& Siadat, 2017c; Mousavi, Vahdani, Hashemi, \& Ebrahimnejad, 2015). Through the years, the necessity for enhancing fuzzy sets theory arose as it was more utilized in real-world problems. One of classical fuzzy sets theory's inadequacies happens when an expert is expected to provide an exact opinion in a number in the interval [0, 1] (Davoudabadi, Mousavi, Šaparauskas, \& Gitinavard, 2019; Haghighi, Mousavi, Antuchevičienè, \& Mohagheghi, 2019; Dorfeshan, Mousavi, Mohagheghi, \& Vahdani, 2018). To overcome this issue, several fuzzy extensions have been proposed. 
For example, intuitionistic fuzzy sets address degrees of membership, non-membership, and hesitancy. This provides the ability to address agreement, disagreement and lack of knowledge in the process (Atanassov, 1994). The same thing is done with different levels of flexibility and constraints in Pythagorean (Yager, 2013) and Neutrosophic fuzzy sets (Smarandache, 2015). Type 2 fuzzy sets utilize fuzzy membership function. The complexity of such sets has led to the development of interval type 2 fuzzy sets (Mendel, John, \& Liu, 2006). Table 10 shows a review of fuzzy set applications in PPS literature.

Table 10. Using fuzzy sets theory in PPS literature

\begin{tabular}{|l|l|}
\hline \multicolumn{1}{|c|}{ Researcher } & \multicolumn{1}{c|}{ Fuzzy approach } \\
\hline Carlsson et al. (2007) & $\begin{array}{l}\text { Fuzzy mixed integer programming model by using } \\
\text { trapezoidal fuzzy number }\end{array}$ \\
\hline $\begin{array}{l}\text { Zhang et al. (2011), Xu et al. (2017), } \\
\text { Li et al. (2014) }\end{array}$ & Credibilistic fuzzy measure \\
\hline Bas (2012) & Fuzzy multidimensional 0-1 knapsack model \\
\hline $\begin{array}{l}\text { Riddell and Wallace (2011), Khalili- } \\
\text { Damghani et al. (2013) }\end{array}$ & Fuzzy rule based approach \\
\hline Fernandez et al. (2013) & Fuzzy outranking relations \\
\hline Zhu and Wang (2012) & $\begin{array}{l}\text { Fuzzy compound real option evaluation model of R\&D } \\
\text { project }\end{array}$ \\
\hline $\begin{array}{l}\text { Abbasianjahromi and Rajaie (2012), } \\
\text { Tavana et al. (2015) }\end{array}$ & fuzzy multi criteria decision-making approach \\
\hline $\begin{array}{l}\text { Perez and Gomez (2016), Perez, Gómez, } \\
\text { Caballero, and Liern (2018) }\end{array}$ & Fuzzy constraints in the model \\
\hline Mohagheghi et al. (2015a) & Intuitionistic fuzzy sets \\
\hline Mohagheghi et al. (2015b) & Interval valued fuzzy sets in mathematical modeling \\
\hline Mohagheghi et al. (2016) & Interval valued fuzzy sets in MADM approach \\
\hline Alexey et al. (2016) & Fuzzy multi-objective model \\
\hline Y. Liu and Y. K. Liu (2017) & Robust fuzzy optimization \\
\hline $\begin{array}{l}\text { Mohagheghi et al. (2017), Wu, Xu, Ke, } \\
\text { Tao, and Li (2019) }\end{array}$ & Interval type 2 fuzzy sets in mathematical modeling \\
\hline Wu et al. (2018) & Triangular intuitionistic fuzzy numbers \\
\hline Lukovac et al. (2017) & Neuro-fuzzy modeling \\
\hline Mohagheghi and Mousavi (2019) & Pythagorean fuzzy sets \\
\hline Dong and Wan (2019) & Fuzzy multi-objective linear programming \\
\hline
\end{tabular}

\subsection{Grey theory}

Another approach in addressing uncertainty in a project environment is using grey theory. Grey systems are effective tool for modeling incomplete information (Julong, 1989). These sets develop a way of presenting vagueness in systems. Grey sets use the basic concepts of grey numbers in grey systems and consider the characteristic function values of a set as grey numbers (Yang \& John, 2012). This trend is new in PPS, and only a few studies have applied these sets. Bhattacharyya (2015) developed a grey approach for R\&D project portfolio 
selection. Balderas, Fernandez, Gomez, and Cruz-Reyes (2017) presented a TOPSIS-Grey approach to handle project portfolio problem. Balderas et al. (2018) also applied the grey mathematical approach to address project portfolio optimization. Zhao, Wu, and Wen (2018) applied grey entropy to discuss the evaluation of green construction projects.

\subsection{Uncertainty theory}

Using uncertainty theory introduced by Liu (2007) is a new approach in addressing project uncertainty. Liu (2007) developed a new uncertain tool based on normality, duality, subadditivity, and product axioms. His presented approach has been used by Huang and Zhao (2014), Huang, Zhao, and Kudratova (2016), Huang and Zhao (2016) and Yan and Ji (2017). Besides, Rough set theory (Tavana et al. 2019) is another approach in addressing uncertainty. Rough set theory applies upper and lower approximations to address uncertainty.

In this section, uncertainty modeling tools in PPS were reviewed. Although different approaches were applied to model uncertainty, given the nature of PPS and the fact that this problem is applicable in various fields, there is no approach that would perfectly suit all the problems. For instance, Mohagheghi et al. (2017) applied type 2 fuzzy sets to PPS, Tavana et al. (2019) applied rough sets, and Huang et al. (2016) used uncertainty theory. Zhou et al. (2019) used hesitant fuzzy information to address portfolio selection. Jiang (2019) applied hesitant fuzzy information in portfolio selection. Mohagheghi and Mousavi (2019) utilized Pythagorean fuzzy sets to address project portfolio selection. However, hybrid methods have not been examined in PPS. In other words, in conditions where different tools work well for different situations, using hybrid tools could improve the approach. Therefore, using hybrid approaches such as fuzzy stochastic methods could be an interesting direction in uncertain PPS.

\section{Modeling approaches}

Archer and Ghasemzadeh (1999) classified the approaches into five main groups of ad hoc methods, comparative methods, scoring approaches, portfolio matrices, and optimization approaches. In another categorization, Iamratanakul et al. (2008) grouped the project selection models into categories of scoring methods, economic methods, mathematical programming, real options analysis, simulation modeling, and heuristics methods. In this paper, in order to present different approaches used to address this problem, first studies introducing frameworks and decision support systems (DSSs) are presented. Then, optimization approaches are addressed. Finally, scoring and ranking methods are reviewed.

\subsection{Frameworks and DSSs}

One approach is PPS studies is introducing frameworks. Frameworks are employed to ease the portfolio selection process and provide flexibility. A framework is also a basis for decision support systems (DSSs). Using framework with computer support can provide several advantages such as recording and retrieving data needed in the analysis, providing computerized 
Table 11. Using framework and DSS in PPS

\begin{tabular}{|l|l|}
\hline \multicolumn{1}{|c|}{ Authors } & \multicolumn{1}{c|}{ Model } \\
\hline Chu et al. (1996) & DSS and Dynamic Programming \\
\hline Archer and Ghasemzadeh (1998) & DSS and Framework \\
\hline Archer and Ghasemzadeh (1999) & Decision making Framework \\
\hline Dong, Lai, and Wang (2005), Martins et al. (2017) & Web based DSS \\
\hline Hu et al. (2008) & DSS and Multi objective IP \\
\hline Stummer and Kiesling (2009) & Multi-criteria DSS \\
\hline Khalili-Damghani et al. (2013) & $\begin{array}{l}\text { Hybrid multi-objective framework: data } \\
\text { mining model with the results from a Data } \\
\text { Envelope Analysis (DEA) model and an } \\
\text { Evolutionary Algorithm (EA) }\end{array}$ \\
\hline Cruz-Reyes et al. (2013) & DSS and SMART method \\
\hline Mira et al. (2013) & DSS software \\
\hline Cruz-Reyes et al. (2014) & DSS by using argumentation theory \\
\hline Hummel, Oliveira, e Costa, and IJzerman (2017) & M-MACBETH DSS \\
\hline
\end{tabular}

algorithms to do the necessary computations, display information, and enabling interaction with available data and aid decision making. In a DSS the software assists in integrating user tasks in each of the decision-making stages smoothly while providing a high level of usability (Archer \& Ghasemzadeh, 1998). Table 11 provides a review of frameworks and DSSs used in PPS studies.

\subsection{Optimization methods}

One of the most common approaches in PPS is using optimization methods. Single, bi, and multi-objective models have been widely used to address this problem. To address uncertainty, stochastic, fuzzy and robust optimization techniques have been used in PPS. In mathematical programming, integer programming (IP), mixed integer programming (MIP), linear programming (LP), non-linear programming (NLP), quadratic programming (QP), etc. are used. However, given the vast area of applications of PPS and its varying features, it cannot be stated that which approach is the best and each problem requires its approach. In Table 12 a review of optimization approaches is provided.

\subsection{Scoring methods}

A wide variety of scoring and ranking methods have been applied in project selection and PPS. Another approach used in this process is using hybrid methods. In these methods, a combination of ranking methods and optimization approaches is used to find the best portfolio of projects. Table 13 presents some of the scoring based methods used in PPS. 
Table 12. Optimization approaches in PPS

\begin{tabular}{|l|l|}
\hline \multicolumn{1}{|c|}{ Authors } & \multicolumn{1}{|c|}{ Model } \\
\hline $\begin{array}{l}\text { Ghasemzadeh, Archer, and Iyogun (1999), Urli and Terrien (2010), Shou } \\
\text { and Huang (2010), Zhu and Wang (2012), Yu, Wang, Wen, and Lai (2012), } \\
\begin{array}{l}\text { Nikkhahnasab and Najafi (2013), Tavana et al. (2015), Hassanzadeh et al. } \\
\text { (2014), Wang and Song (2016) }\end{array}\end{array}$ & $\begin{array}{l}\text { Integer } \\
\text { Programming }\end{array}$ \\
\hline $\begin{array}{l}\text { Doerner et al. (2006), Li et al. (2012), Rabbani et al. (2013), Jafarzadeh et al. } \\
\text { (2015) }\end{array}$ & $\begin{array}{l}\text { Integer Linear } \\
\text { Programming }\end{array}$ \\
\hline $\begin{array}{l}\text { Carlsson et al. (2007), Bas (2012), Zhu and Wang (2012), Li et al. (2014), } \\
\text { Qin et al. (2014), Jingmei and Peng (2015), Wu, Xu, Ke, Chen, and Sun } \\
\text { (2018), Lifshits and Avdoshin (2016) }\end{array}$ & Fuzzy programming \\
\hline $\begin{array}{l}\text { Riddell and Wallace (2007), Gutjahr et al. (2008), Gutjahr and Reiter (2010), } \\
\text { Naderi (2013), Li et al. (2015), Gang et al. (2015), Ghodoosi, Maftahi, \& } \\
\text { Yousefi (2016), Sefair et al. (2017), Schaeffer and Cruz-Reyes (2016), } \\
\text { Li et al. (2018) }\end{array}$ & $\begin{array}{l}\text { Mixed integer } \\
\text { Programming }\end{array}$ \\
\hline $\begin{array}{l}\text { Hu et al. (2008), Gutjahr et al. (2010), Urli and Terrien (2010), Carazo et al. } \\
\text { (2010), Fernandez et al. (2013), Rabbani et al. (2013), Hassanzadeh et al. } \\
\text { (2014), Perez and Gomez (2014), Gang et al. (2015), Roland, Figueira, and } \\
\text { De Smet (2016), Wu et al. (2018), Mohagheghi et al. (2016), Lifshits and } \\
\text { Avdoshin (2016) }\end{array}$ & $\begin{array}{l}\text { Multi objective } \\
\text { programming }\end{array}$ \\
\hline $\begin{array}{l}\text { Gutjahr et al. (2008), Guo, Liang, Zhu, and Hu (2008), Gutjahr and Reiter } \\
\text { (2010), Urli and Terrien (2010), Yu et al. (2012), Hall et al. (2015), Carazo } \\
\text { (2015), Jingmei and Peng (2015), Ghodoosi et al. (2016), Li et al. (2018) }\end{array}$ & $\begin{array}{l}\text { Non-linear } \\
\text { Programming }\end{array}$ \\
\hline $\begin{array}{l}\text { Gurgur (2009), Gutjahr and Reiter (2010), Gutjahr and Froeschl (2013), } \\
\text { Mavrotas and Pechak (2013a), Mavrotas and Pechak (2013b), Mavrotas and } \\
\text { Pechak (2013), Yang et al. (2015) }\end{array}$ & $\begin{array}{l}\text { Stochastic } \\
\text { Programming }\end{array}$ \\
\hline $\begin{array}{l}\text { Zhang et al. (2011), Mohagheghi et al. (2015b), Mohagheghi et al., (2017a), } \\
\text { Li et al. (2018) }\end{array}$ & $\begin{array}{l}\text { Semi-variance, mean } \\
\text { variance models }\end{array}$ \\
\hline Sheng and Chen (2011), Sefair et al. (2017) & $\begin{array}{l}\text { Quadratic } \\
\text { programming }\end{array}$ \\
\hline
\end{tabular}

In this section, modeling approaches were reviewed. Various models have been developed to attend to PPS (e.g., Gutjahr \& Reiter, 2010; Sefair et al., 2017; Schaeffer \& Cruz-Reyes, 2016; Li, Wang, Yan, \& Zhao, 2018). Such approaches limit the ability of top managers in the process of PPS. Moreover, there are some complex limitations that cannot be properly presented in the mathematical model or would form a model that is almost impossible to optimize. Various scoring studies have been also given in project management (e.g., Brauers \& Zavadskas, 2010; Zavadskas, Turskis, Tamošaitiené, \& Marina, 2008; Zavadskas, Vilutienè, Turskis, \& Šaparauskas, 2014; Zavadaskas, Turskis, Vilutiene, \& Lepkova, 2017b) and PPS (e.g., Debnath et al., 2017; Balderas et al., 2017). Such methods are based on judgments and are easily affected by opinions of experts. PPS is concerned with qualitative and quantitative data; therefore, it is often better to form frameworks that use both the scoring methods and the mathematical models (e.g. Tavana et al., 2015; Mohagheghi et al., 2016). A comparison of PPS studies with similar managerial problems suggests that in PPS expert systems have not been comprehensively applied. To put differently, forming proper expert systems could result in utilizing the expertise of managers and benefiting from various modeling and scoring methods. 
Table 13. Ranking and scoring approaches in PPS

\begin{tabular}{|l|l|}
\hline \multicolumn{1}{|c|}{ Authors } & \multicolumn{1}{c|}{ Model } \\
\hline $\begin{array}{l}\text { Ghaeli et al. (2003), Koppinen and Rosqvist } \\
\text { (2010), Conka et al. (2008) }\end{array}$ & AHP \\
\hline $\begin{array}{l}\text { Conka et al. (2008), Khalili-Damghani et al. } \\
\text { (2013), Tavana et al. (2015) }\end{array}$ & Data Envelopment Analysis (DEA) \\
\hline Fouladgar et al. (2011) & Vikor \\
\hline Riddell and Wallace (2011) & Fuzzy rule-based aggregation procedure \\
\hline Khalili-Damghani and Sadi-Nezhad (2013b) & Evolutionary Algorithm (EA) \\
\hline Abbasianjahromi and Rajaie (2012) & SAW \\
\hline Khalili-Damghani et al. (2013) & Balance score card (BSC) \\
\hline Khalili-Damghani and Tavana (2014) & Structural Equation Modeling \\
\hline Jeng and Huang (2015) & $\begin{array}{l}\text { Modified Delphi method (MDM), a decision-making } \\
\text { trial and evaluation laboratory (DEMATEL) method, } \\
\text { and an analytic network process (ANP) }\end{array}$ \\
\hline Tavana et al. (2015), Balderas et al. (2017) & TOPSIS \\
\hline Hummel et al. (2017), Debnath et al. (2017) & $\begin{array}{l}\text { Measuring Attractiveness by a Categorical Based } \\
\text { Evaluation Technique (MACBETH) }\end{array}$ \\
\hline Debnath et al. (2017) & $\begin{array}{l}\text { Decision-Making Trial and Evaluation Laboratory } \\
\text { (DEMATEL) }\end{array}$ \\
\hline
\end{tabular}

\section{Solution approaches}

In this section, a review of solution approaches applied in mathematical modeling approaches of PPS is presented. Given the variety of PPS modeling approaches and applications, several approaches have been used to find the best project portfolio. The applied approaches are categorized into main groups of exact, inexact, and heuristics approaches.

\subsection{Exact}

Given the characteristics of PPS mathematical models, exact approaches were used in some of the studies to address small size problems. CPLEX has been used as an appropriate solver in some studies to obtain the exact solution. Bender's decomposition has been used to address the solution approach of some of the studies. Another common approach is obtaining linear and solvable equivalents through linearization methods. To better illustrate the exact approaches, Table 14 is presented.

Table 14. Exact approaches applied in PPS

\begin{tabular}{|l|l|}
\hline \multicolumn{1}{|c|}{ Authors } & \multicolumn{1}{c|}{ Solution Approach } \\
\hline Hassanzadeh et al. (2014a) & Robust optimization for uncertain linear programming \\
\hline Hassanzadeh et al. (2014b) & Robust augmented weighted Tchebycheff programs \\
\hline Hall et al. (2015), Sefair et al. (2017) & Benders decomposition \\
\hline Roland et al. (2016) & Cutting-plane approach \\
\hline Y. Liu and Y. K. Liu (2017) & The equivalent analytical expressions of credibility constraints \\
\hline
\end{tabular}




\subsection{Heuristic and meta-heuristic}

PPS can be developed in the form of a multi-objective combinatorial optimization (MOCO) problem. In MOCO, obtaining the non-dominated or Pareto-optimal portfolio candidates forms an NP-hard problem. As a result, (meta) heuristic methods are needed to perform tradeoffs among solution quality and the effort required to obtain an acceptable approximation of the solution space (Doerner et al., 2006). Doerner et al. (2006) developed a mathematical model to handle PPS. They worked on a generalization of the classical bin packing problem that made the model NP-hard. Tofighian et al. (2018) developed a model that handled risks, stochastic incomes, and the possibility of investing extra budget in each time period. Their model was NP-hard and required a meta-heuristic solution approach. Panadero, Doering, Kizys, Juan, and Fito (2018) suggested that by increasing the pool of project proposals and consideration of realistic constraints, PPS becomes NP-hard. Therefore, they presented a variable neighborhood search semi-heuristic for PPS. Wang and Song (2016) presented a NP-hard model with consideration of reinvestment strategy for PPS and scheduling with time-dependent budget. Çağlar and Gürel (2017) addressed public R\&D PPS problems with cancellations by introducing a NP-hard model. Shariatmadari, Nahavandi, Zegordi, and Sobhiyah (2017) proposed a PPS and scheduling model that was NP-hard. To conclude, in order to address NP-Hard PPS models, several heuristics and meta-heuristics approaches were applied and developed. Table 15 provides a review of different approaches applied in PPS methods.

Table 15. Heuristic and meta-heuristic approaches

\begin{tabular}{|l|l|}
\hline \multicolumn{1}{|c|}{ Authors } & \multicolumn{1}{c|}{ Solution Approach } \\
\hline $\begin{array}{l}\text { Doerner et al. (2006), Gutjahr et al. (2008), Gutjahr } \\
\text { and Reiter (2010), Rivera et al. (2013), Lifshits and } \\
\text { Avdoshin (2016) }\end{array}$ & Ant colony optimization \\
\hline Gutjahr et al. (2008) & Greedy heuristic \\
\hline $\begin{array}{l}\text { Gutjahr et al. (2010), Gutjahr and Reiter (2010), } \\
\text { Khalili-Damghani and Sadi-Nezhad (2013b), Fernandez } \\
\text { et al. (2013), Wu et al. (2018), Balderas et al. (2017) }\end{array}$ & NSGAII \\
\hline Urli and Terrien (2010) & SSPMO \\
\hline Carazo et al. (2010) & Scatter Search \\
\hline Shou and Huang (2010) & $\begin{array}{l}\text { Fast heuristic based on the serial schedule } \\
\text { generation scheme }\end{array}$ \\
\hline & The traversal algorithm. \\
\hline Gutjahr and Froeschl (2013), Panadero et al. (2018) & Variable Neighborhood Search (VNS) \\
\hline $\begin{array}{l}\text { Zhang et al. (2011), Gutjahr et al. (2008), Yu et al. } \\
\text { (2012), Nikkhahnasab and Najafi (2012), Naderi (2013), } \\
\text { Li et al. (2014) }\end{array}$ & Genetic algorithm \\
\hline & NOSGA-II \\
\hline Mira et al. (2012) & GRASP-based heuristic \\
\hline Li et al. (2012) & $\begin{array}{l}\text { Heuristic based on dynamic } \\
\text { programming and graph theory }\end{array}$ \\
\hline Nikkhahnasab and Najafi (2012), Naderi (2013) & Simulated annealing \\
\hline
\end{tabular}


End of Table 15

\begin{tabular}{|l|l|}
\hline \multicolumn{1}{|c|}{ Authors } & \multicolumn{1}{c|}{ Solution Approach } \\
\hline Naderi (2013) & The imperialist competitive algorithm \\
\hline Rabbani et al. (2013) & $\begin{array}{l}\text { Multi-objective differential evolution } \\
\text { (MODE) }\end{array}$ \\
\hline Esfahani and Yousefi (2016) & Harmony search algorithm \\
\hline Jingmei and Peng (2015) & Improved quantum genetic algorithm \\
\hline Lifshits and Avdoshin (2016) & SPEA II method \\
\hline Ghodoosi et al. (2016) & $\begin{array}{l}\text { Multi-objective shuffle frog leaping } \\
\text { algorithm (SFLA) }\end{array}$ \\
\hline
\end{tabular}

\section{Applications and real-life case studies}

Given the characteristics of PPS, an important aspect of PPS studies is using them in real-life case studies. Therefore, in this section, a review of areas where PPS studies have been applied is presented. The application of PPS studies covers a wide range of fields. A review of studies shows that case studies in different areas such as nuclear energy, oil and gas industry, construction industry, research institutes, etc. were carried out. Table 16 shows case studies in PPS papers.

Table 16. Areas of real-life case studies of PPS studies

\begin{tabular}{|l|l|}
\hline \multicolumn{1}{|c|}{ Researcher } & \multicolumn{1}{|c|}{ Applications and real-life case study } \\
\hline Ghaeli, Vavrik, and Nasvadi (2003) & Intelligent Transportation Systems \\
\hline Olundh and Ritzen (2004) & Structured development process of Scania \\
\hline Riddell and Wallace (2007) & $\begin{array}{l}\text { Determining funding levels for R\&D projects } \\
\text { for the particular example of the Nuclear } \\
\text { Emergency Safety Team (NEST) }\end{array}$ \\
\hline $\begin{array}{l}\text { Gutjahr et al. (2008), Stummer et al. (2009), } \\
\text { Gutjahr et al. (2010), Gutjahr and Reiter (2010), } \\
\text { Gutjahr and Froeschl (2013) }\end{array}$ & $\begin{array}{l}\text { The Electronic Commerce Competence Center } \\
\text { (EC3) Austria }\end{array}$ \\
\hline Bhattacharyya et al. (2010) & $\begin{array}{l}\text { Large scale organization B. M. Enterprise, } \\
\text { Berhampore, West Bengal, India }\end{array}$ \\
\hline $\begin{array}{l}\text { Bas (2012), Abbasianjahromi and Rajaie (2012), } \\
\text { Mohagheghi et al. (2015b) }\end{array}$ & Construction project portfolio \\
\hline $\begin{array}{l}\text { Zhu and Wang (2012), Mohagheghi et al. (2017a), } \\
\text { Sefair et al. (2017), Yan and Ji (2017), Tang et al. } \\
\text { (2017) }\end{array}$ & Oil and gas industry \\
\hline $\begin{array}{l}\text { Li et al (2012), Khalili-Damghani and Tavana } \\
\text { (2014) }\end{array}$ & Financial company \\
\hline $\begin{array}{l}\text { Mira et al. (2013), Mavrotas and Pechak (2013a), } \\
\text { (2013b) }\end{array}$ & Energy and power generation \\
\hline Jeng and Huang (2015), Gang et al. (2015) & Research institutes \\
\hline Jadda and Idrissi (2015) & Case study of a Moroccan public organization \\
\hline Hummel et al. (2017) & $\begin{array}{l}\text { Robotic innovations for minimal invasive } \\
\text { surgical interventions }\end{array}$ \\
\hline Martins et al. (2017) & $\begin{array}{l}\text { Sustainable strategic decision making in an } \\
\text { electricity company }\end{array}$ \\
\hline
\end{tabular}




\section{Conclusions and directions for further research}

As the review of PPS studies suggests, the number of studies on this subject has increased in recent years This is mainly due to recognition of the vitality of possessing well-established methods for practical project portfolio management. In this paper, the papers on PPS were reviewed based on the evaluation criteria, uncertainty modeling, selection approach, solution approach and area of application. To shed light on new insights for further research, this section presents a review of recent trends, literature gaps in addition to future research directions.

Some of the recent trends in PPS studies are as follows:

- The financial criteria are no more the only or the most important factors and other aspects of project portfolios are recently addressed in PPS studies. Considering the social and environmental aspects of project portfolios is one of the recent trends applied in PPS.

- Some of the issues related to strategic management were recently added to PPS literature. Reinvestment strategy, flexible time horizon, and strategic alignment are some of the issues associated with strategic management.

- PPS is a part of project portfolio management. To make this step more thorough, project implementation and management should be addressed in this process. One of the recent trends in the literature is the simultaneous consideration of project portfolio selection and project portfolio scheduling.

- One of the recent trends is using downside risk measure to address project risk. In this approach, only the negative impacts and outcomes are considered. For instance, in common financial assessments, all the variations from the expected net present value are considered as a risk while in reality, only the negative deviations harm the portfolio. Therefore, in financial assessment using lower semivariance is more efficient than finding all variations as a risk.

- To address uncertainty, fuzzy set theory, stochastic and grey uncertainty were used. One new trend in recent years is using new fuzzy extensions in order to improve modeling uncertainty. Type 2 fuzzy sets, intuitionistic fuzzy sets, and interval-valued fuzzy sets are some of the methods applied.

- Given the features of PPS studies, a new trend is presenting frameworks that consist of both MADM and MODM techniques. For instance, one approach was using DEA, TOPSIS, and LP in PPS. Such approaches improve the flexibility of the process and provide more power in addressing various sorts of data.

- Since in recent years more optimization approaches have been introduced, one new trend is using Meta-heuristics and heuristics to find the solution of mathematical models.

- Using uncertainty theory presented by Liu (2007) is a new approach in addressing uncertainty in the project environment that will improve the existing methods.

Some of the main gaps that were recognized in this study are as follows:

- Despite addressing sustainability in PPS studies, sustainability criteria are not still comprehensively addressed. In other words, the criteria are not yet tailored for the project management environment. 
- Projects suffer from unexpected events and unpleasant surprises. In other words, project success and achieving the goals of projects depend on the ability of projects to withstand harmful events. Therefore, one criterion that would improve the evaluation of projects and project portfolios is project resilience that is not yet addressed in the literature.

- Using hybrid methods in addressing uncertainty would improve the existing methods. In other words, applying methods such as fuzzy stochastic approaches would improve the existing methods in addressing uncertainty.

- Several DSSs were introduced in the literature to help decision-making in the process of PPS. However, yet the literature is very weak when it comes to developing expert system. To put it differently, since projects are unique and experts' opinions in some cases are priceless, using expert systems would highly improve the entire process in PPS.

- Combining the existing uncertain optimization methods with modeling approaches in PPS is not yet well addressed in the literature. In other words, interval optimization, stochastic optimization, and fuzzy optimization techniques are still new to the literature.

- The literature is weak when it comes to using exact solution approaches. Methods such as Lagrangian relaxation, benders decomposition, and branching techniques are still new to the literature.

- In MADM based approaches, issues like decision-makers' weights, criteria's subjective and objective weights, aggregation steps, and decision indexes are not yet fully addressed in the literature.

However, to overcome the gaps of PSP, in the following some of the possible future trends are presented:

- Addressing sustainability through project portfolio selection by using multi-objective optimization methods is a future trend that helps in addressing sustainability through optimization techniques.

- Project portfolio evaluation, project portfolio implementation, and management should all be addressed together to achieve more efficiency in the methods. In this approach, methods such as reinvestment strategy and project scheduling will be addressed in the PPS method.

- Given the importance of globalization in today's decision-making problems, an important and practical future research direction is addressing an international issue such as foreign investment and exchange rates in project portfolio evaluations.

- Using the advantages of earned value analysis in PPS could improve the process. Therefore, using project progress evaluation techniques in PPS is a future trend that could enhance the process.

- Using fuzzy optimization techniques to address uncertain multi-objective optimization approaches in PPS is a future trend that has the merits of MODM and fuzzy optimization.

- Using fuzzy stochastic approaches to address project uncertainty is a possible future trend that would provide the methods with the merits of fuzzy and stochastic methods. 
- Another interesting future trend is developing proper expert systems to employ the expertise of managers and benefit from various modeling and scoring methods. There are various expert systems that can be applied in PPS studies. A very interesting possible future research direction is using different sorts of expert systems (i.e. rule-based expert system, frame-based expert system, fuzzy expert system, neural expert system, and neuro-fuzzy expert system) and explores the pros and cons of different expert systems under different PPS conditions.

\section{Acknowledgements}

The authors express sincere appreciation to the editor and anonymous reviewers for their constructive comments which are helpful in enhancing the original version.

\section{Author contribution}

V. Mohagheghi and S. M. Mousavi designed the research, analyzed the data and the obtained results and developed the paper. J. Antuchevičienè and M. Mojtahedi provided extensive advice throughout the study regarding the research design, methodology and findings. All the authors have read and approved the final manuscript.

\section{Disclosure statement}

The authors declare that they have any competing financial, professional, or personal interests from other parties.

\section{References}

Abbasianjahromi, H., \& Rajaie, H. (2012). Developing a project portfolio selection model for contractor firms considering the risk factor. Journal of Civil Engineering and Management, 18(6), 879-889. https://doi/abs/10.3846/13923730.2012.734856

Archer, N. P., \& Ghasemzadeh, F. (1998). A decision support system for project portfolio selection. International Journal of Technology Management, 16(1-3), 105-114.

Archer, N. P., \& Ghasemzadeh, F. (1999). An integrated framework for project portfolio selection. International Journal of Project Management, 17(4), 207-216. https://doi.org/10.1016/S0263-7863(98)00032-5

Aritua, B., Smith, N. J., \& Bower, D. (2009). Construction client multi-projects-A complex adaptive systems perspective. International Journal of Project Management, 27(1), 72-79. https://doi.org/10.1016/j.ijproman.2008.02.005

Atanassov, K. T. (1994). New operations defined over the intuitionistic fuzzy sets. Fuzzy Sets and Systems, 61(2), 137-142. https://doi.org/10.1016/0165-0114(94)90229-1

Balderas, F., Fernandez, E., Gomez, C., \& Cruz-Reyes, L. (2017). TOPSIS-grey method applied to project portfolio problem. In Nature-inspired design of hybrid intelligent systems (pp. 767-774). Springer International Publishing. https://doi.org/10.1007/978-3-319-47054-2_51

Balderas, F., Fernandez, E., Gomez-Santillan, C., Cruz-Reyes, L., Rangel-Valdez, N., \& Morales-Rodríguez, M. L. (2018). A grey mathematics approach for evolutionary multi-objective metaheuristic 
of project portfolio selection. In Fuzzy logic augmentation of neural and optimization algorithms: theoretical aspects and real applications (pp. 379-388). Cham: Springer.

https://doi.org/10.1007/978-3-319-71008-2_27

Bas, E. (2012). Surrogate relaxation of a fuzzy multidimensional 0-1 knapsack model by surrogate constraint normalization rules and a methodology for multi-attribute project portfolio selection. Engineering Applications of Artificial Intelligence, 25(5), 958-970. https://doi.org/10.1016/j.engappai.2011.09.015

Better, M., \& Glover, F. (2006). Selecting project portfolios by optimizing simulations. The Engineering Economist, 51(2), 81-97. https://doi.org/10.1080/00137910600695593

Bhattacharyya, R. (2015). A grey theory based multiple attribute approach for R\&D project portfolio selection. Fuzzy Information and Engineering, 7(2), 211-225. https://doi.org/10.1016/j.fiae.2015.05.006

Bhattacharyya, R., Chatterjee, A., \& Kar, S. (2010). Uncertainty theory based novel multi-objective optimization technique using embedding theorem with application to R \& $\mathrm{D}$ project portfolio selection. Applied Mathematics, 1(03), 189-199. https://doi.org/10.4236/am.2010.13023

Brauers, W. K. M., \& Zavadskas, E. K. (2010). Project management by MULTIMOORA as an instrument for transition economies. Technological and Economic Development of Economy, 16(1), 5-24. https://doi/abs/10.3846/tede.2010.01

Çağlar, M., \& Gürel, S. (2017). Public R\&D project portfolio selection problem with cancellations. OR Spectrum, 39(3), 659-687. https://doi.org/10.1007/s00291-016-0468-5

Carazo, A. F. (2015). Multi-criteria project portfolio selection. In Handbook on project management and scheduling (Vol. 2, pp. 709-728). Springer International Publishing. https://doi.org/10.1007/978-3-319-05915-0_3

Carazo, A. F., Gómez, T., Molina, J., Hernández-Díaz, A. G., Guerrero, F. M., \& Caballero, R. (2010). Solving a comprehensive model for multiobjective project portfolio selection. Computers \& Operations Research, 37(4), 630-639. https://doi.org/10.1016/j.cor.2009.06.012

Carlsson, C., Fullér, R., Heikkilä, M., \& Majlender, P. (2007). A fuzzy approach to R\&D project portfolio selection. International Journal of Approximate Reasoning, 44(2), 93-105. https://doi.org/10.1016/j.ijar.2006.07.003

Chu, P. Y. V., Hsu, Y. L., \& Fehling, M. (1996). A decision support system for project portfolio selection. Computers in Industry, 32(2), 141-149. https://doi.org/10.1016/S0166-3615(96)00067-X

Conka, T., Vayvay, O., \& Sennaroglu, B. (2008). A combined decision model for R\&D project portfolio selection. International Journal of Business Innovation and Research, 2(2), 190-202. https://doi.org/10.1504/IJBIR.2008.016652

Cruz-Reyes, L., Medina, C., \& López, F. (2013). An interactive decision support system framework for social project portfolio selection. In Recent advances on hybrid intelligent systems (pp. 377-391). Berlin, Heidelberg: Springer. Retrieved from https://link.springer.com/chapter/10.1007/978-3-642-33021-6_30

Cruz-Reyes, L., Trejo, C. M., Irrarragorri, F. L., \& Santillán, C. G. G. (2014). A decision support system framework for public project portfolio selection with argumentation theory. In Recent advances on hybrid approaches for designing intelligent systems (pp. 467-479). Springer International Publishing. Retrieved from https://link.springer.com/chapter/10.1007\%2F978-3-319-05170-3_32

Davoudabadi, R., Mousavi, S. M., Šaparauskas, J., \& Gitinavard, H. (2019). Solving construction project selection problem by a new uncertain weighting and ranking based on compromise solution with linear assignment approach. Journal of Civil Engineering and Management, 25(3), 241-251. https://doi.org/10.3846/jcem.2019.8656

Debnath, A., Roy, J., Kar, S., Zavadskas, E. K., \& Antucheviciene, J. (2017). A hybrid MCDM approach for strategic project portfolio selection of agro by-products. Sustainability, 9(8), 1302.

https://doi.org/10.3390/su9081302 
Dobrovolskienè, N., \& Tamošiūnienė, R. (2016). Sustainability-oriented financial resource allocation in a project portfolio through multi-criteria decision-making. Sustainability, 8(5), 485. Retrieved from https://www.mdpi.com/2071-1050/8/5/485

Doerner, K. F., Gutjahr, W. J., Hartl, R. F., Strauss, C., \& Stummer, C. (2006). Pareto ant colony optimization with ILP preprocessing in multiobjective project portfolio selection. European Journal of Operational Research, 171(3), 830-841. https://doi.org/10.1016/j.ejor.2004.09.009

Dong, J., \& Wan, S. (2019). A new method for solving fuzzy multi-objective linear programming problems. Iranian Journal of Fuzzy Systems, 16(3), 145-159.

Dong, J., Lai, K. K., \& Wang, S. (2005). XML-based schemes for business project portfolio selection. In Data mining and knowledge management (pp. 254-262). Berlin, Heidelberg: Springer. https://doi.org/10.1007/978-3-540-30537-8_28

Dorfeshan, Y., Mousavi, S. M., Mohagheghi, V., \& Vahdani, B. (2018). Selecting project-critical path by a new interval type-2 fuzzy decision methodology based on MULTIMOORA, MOOSRA and TPOP methods. Computers \& Industrial Engineering, 120, 160-178. https://doi.org/10.1016/j.cie.2018.04.015

Ebrahimnejad, S., Mousavi, S. M., Tavakkoli-Moghaddam, R., Hashemi, H., \& Vahdani, B. (2012). A novel two-phase group decision making approach for construction project selection in a fuzzy environment. Applied Mathematical Modelling, 36(9), 4197-4217.

https://doi.org/10.1016/j.apm.2011.11.050

Ebrahimnejad, S., Mousavi, S. M., Tavakkoli-Moghaddam, R., \& Heydar, M. (2014). Risk ranking in mega projects by fuzzy compromise approach: A comparative analysis. Journal of Intelligent and Fuzzy Systems, 26, 949-959. https://doi.org/10.3233/IFS-130785

Esfahani, H. N., Hossein Sobhiyah, M., \& Yousefi, V. R. (2016). Project portfolio selection via harmony search algorithm and modern portfolio theory. Procedia-Social and Behavioral Sciences, 226, 51-58. https://doi.org/10.1016/j.sbspro.2016.06.161

Farshchian, M. M., \& Heravi, G. (2018). Probabilistic assessment of cost, time, and revenue in a portfolio of projects using stochastic agent-based simulation. Journal of Construction Engineering and Management, 144(5). https://doi.org/10.1061/(ASCE)CO.1943-7862.0001476

Felberbauer, T., Gutjahr, W. J., \& Doerner, K. F. (2018). Stochastic project management: multiple projects with multi-skilled human resources. Journal of Scheduling, 22(3), 271-288. https://doi.org/10.1007/s10951-018-0592-y

Fernandez, E., Lopez, E., Mazcorro, G., Olmedo, R., \& Coello, C. A. C. (2013). Application of the nonoutranked sorting genetic algorithm to public project portfolio selection. Information Sciences, 228, 131-149. https://doi.org/10.1016/j.ins.2012.11.018

Fouladgar, M. M., Yazdani-Chamzini, A., Yakhchali, S. H., Ghasempourabadi, M. H., \& Badri, N. (2011, September). Project portfolio selection using VIKOR technique under fuzzy environment. In 2nd International Conference on Construction and Project Management (pp. 236-240). Retrieved from https://www.academia.edu/download/11495265/46-iccpm2011a10032

Gang, J., Hu, R., Wu, T., Tu, Y., Feng, C., \& Li, Y. (2015). R\&D project portfolio selection in a bi-level investment environment: a case study from a research institute in China. In Proceedings of the Ninth International Conference on Management Science and Engineering Management (pp. 563-574). Berlin, Heidelberg: Springer. https://doi.org/10.1007/978-3-662-47241-5_48

Ghaeli, M., Vavrik, J., \& Nasvadi, G. (2003). Multicriteria project portfolio selection: Case study for intelligent transportation systems. Transportation Research Record: Journal of the Transportation Research Board, 1848(1), 125-131. https://doi.org/10.3141/1848-18

Ghasemzadeh, F., Archer, N., \& Iyogun, P. (1999). A zero-one model for project portfolio selection and scheduling. Journal of the Operational Research Society, 50(7), 745-755.

https://doi.org/10.1057/palgrave.jors.2600767 
Ghassemi, A., \& Amalnick, M. (2018). NPD project portfolio selection using reinvestment strategy in competitive environment. International Journal of Industrial Engineering Computations, 9(1), 47-62. https://doi.org/10.5267/j.ijiec.2017.5.001

Ghodoosi, M. R., Maftahi, R., \& Yousefi, V. (2016). Proposing a hybrid approach to predict, schedule and select the most robust project portfolio under uncertainty. European Online Journal of Natural and Social Sciences, 5(4), 1099-1110. http://european-science.com/eojnss/article/view/4707

Graves, S. B., Ringuest, J. L., \& Medaglia, A. L. (2003). Conditional stochastic dominance in project portfolio selection. In Models \& methods for project selection (pp. 77-93). US: Springer. https://doi.org/10.1007/978-1-4615-0280-7_6

Guo, P., Liang, J. J., Zhu, Y. M., \& Hu, J. F. (2008, December). R\&D project portfolio selection model analysis within project interdependencies context. In 2008 IEEE International Conference on Industrial Engineering and Engineering Management (pp. 994-998), Singapore. IEEE. https://doi.org/10.1109/IEEM.2008.4738019

Gurgur, C. (2009). Optimal project portfolio selection with carryover constraint. Journal of the Operational Research Society, 60(12), 1649-1657. https://doi.org/10.1057/jors.2008.104

Gutjahr, W. J., \& Froeschl, K. A. (2013). Project portfolio selection under uncertainty with outsourcing opportunities. Flexible Services and Manufacturing Journal, 25(1-2), 255-281. https://doi.org/10.1007/s10696-011-9107-2

Gutjahr, W. J., \& Reiter, P. (2010). Bi-objective project portfolio selection and staff assignment under uncertainty. Optimization, 59(3), 417-445. https://doi.org/10.1080/02331931003700699

Gutjahr, W. J., Katzensteiner, S., Reiter, P., Stummer, C., \& Denk, M. (2010). Multi-objective decision analysis for competence-oriented project portfolio selection. European Journal of Operational Research, 205(3), 670-679. https://doi.org/10.1016/j.ejor.2010.01.041

Gutjahr, W. J., Katzensteiner, S., Reiter, P., Stummer, C., \& Denk, M. (2008). Competence-driven project portfolio selection, scheduling and staff assignment. Central European Journal of Operations Research, 16(3), 281-306. https://doi.org/10.1007/s10100-008-0057-z

Haghighi, M. H., Mousavi, S. M., Antuchevičienė, J., \& Mohagheghi, V. (2019). A new analytical methodology to handle time-cost trade-off problem with considering quality loss cost under intervalvalued fuzzy uncertainty. Technological and Economic Development of Economy, 25(2), 277-299. https://doi.org/10.3846/tede.2019.8422

Hall, N. G., Long, D. Z., Qi, J., \& Sim, M. (2015). Managing underperformance risk in project portfolio selection. Operations Research, 63(3), 660-675. https://doi.org/10.1287/opre.2015.1382

Hannah, L. A. (2015). Stochastic optimization. International Encyclopedia of the Social \& Behavioral Sciences, 2, 473-481. https://doi.org/10.1016/B978-0-08-097086-8.42010-6

Hashemi, H., Mousavi, S. M., \& Mojtahedi, S. M. H. (2011). Bootstrap technique for risk analysis with interval numbers in bridge construction projects. Journal of Construction Engineering and Management - ASCE, 137(8), 600-608. https://doi.org/10.1061/(ASCE)CO.1943-7862.0000344

Hashemi, H., Mousavi, S. M., Tavakkoli-Moghaddam, R., \& Gholipour, Y. (2013). Compromise ranking approach with bootstrap confidence intervals for risk assessment in port management projects. Journal of Management in Engineering, 29(4), 334-344. https://doi.org/10.1061/(ASCE)ME.1943-5479.0000167

Hassanzadeh, F., Modarres, M., Nemati, H. R., \& Amoako-Gyampah, K. (2014a). A robust R\&D project portfolio optimization model for pharmaceutical contract research organizations. International Journal of Production Economics, 158, 18-27. https://doi.org/10.1016/j.ijpe.2014.07.001

Hassanzadeh, F., Nemati, H., \& Sun, M. (2014b). Robust optimization for interactive multiobjective programming with imprecise information applied to R\&D project portfolio selection. European Journal of Operational Research, 238(1), 41-53. https://doi.org/10.1016/j.ejor.2014.03.023 
Hu, G., Wang, L., Fetch, S., \& Bidanda, B. (2008). A multi-objective model for project portfolio selection to implement lean and Six Sigma concepts. International Journal of Production Research, 46(23), 6611-6625. https://doi.org/10.1080/00207540802230363

Hu, Q. J., \& Szmerekovsky, J. (2016). Project portfolio selection: a newsvendor approach. Decision Sciences, 48(1), 176-199. https://doi.org/10.1111/deci.12214

Huang, X., \& Zhao, T. (2014). Project selection and scheduling with uncertain net income and investment cost. Applied Mathematics and Computation, 247, 61-71. https://doi.org/10.1016/j.amc.2014.08.082

Huang, X., \& Zhao, T. (2016). Project selection and adjustment based on uncertain measure. Information Sciences, 352, 1-14. https://doi.org/10.1016/j.ins.2016.02.050

Huang, X., Zhao, T., \& Kudratova, S. (2016). Uncertain mean-variance and mean-semivariance models for optimal project selection and scheduling. Knowledge-Based Systems, 93, 1-11.

https://doi.org/10.1016/j.knosys.2015.10.030

Humel, J. M., Oliveira, M. D., e Costa, C. A. B., \& IJzerman, M. J. (2017). Supporting the project portfolio selection decision of research and development investments by means of multi-criteria resource allocation modelling. In Multi-criteria decision analysis to support healthcare decisions (pp. 89-103). Cham: Springer. https://doi.org/10.1007/978-3-319-47540-0_6

Hutchins, M. J., \& Sutherland, J. W. (2008). An exploration of measures of social sustainability and their application to supply chain decisions. Journal of Cleaner Production, 16(15), 1688-1698. https://doi.org/10.1016/j.jclepro.2008.06.001

Jadda, S., \& Idrissi, M. A. J. (2015, October). Strategic alignment and information system project portfolio optimization model. In 2015 10th International Conference on Intelligent Systems: Theories and Applications (SITA) (pp. 1-8). IEEE. https://doi.org/10.1109/SITA.2015.7358385

Jafarzadeh, M., Tareghian, H. R., Rahbarnia, F., \& Ghanbari, R. (2015). Optimal selection of project portfolios using reinvestment strategy within a flexible time horizon. European Journal of Operational Research, 243(2), 658-664. https://doi.org/10.1016/j.ejor.2014.12.013

Jeng, D. J. F., \& Huang, K. H. (2015). Strategic project portfolio selection for national research institutes. Journal of Business Research, 68(11), 2305-2311. https://doi.org/10.1016/j.jbusres.2015.06.016

Jiang, J. (2018, June 9-13). System portfolio selection under hesitant fuzzy information. In Y. Chen, G. Kersten, R. Vetschera, \& H. Xu (Eds.), Group Decision and Negotiation in an Uncertain World: 18th International Conference, GDN 2018 (Vol. 315, p. 33-34), Nanjing, China. Cham: Springer. https://doi.org/10.1007/978-3-319-92874-6_3

Jingmei, W., \& Peng, G. (2015, August). The robustness risk and selection optimization of R\&D project portfolio under uncertainty. In 2015 IEEE International Conference on Grey Systems and Intelligent Services (pp. 622-627). IEEE. https://doi.org/10.1109/GSIS.2015.7301817

Julong, D. (1989). Introduction to grey system theory. The Journal of Grey System, 1(1), 1-24.

Kaiser, M. G., El Arbi, F., \& Ahlemann, F. (2015). Successful project portfolio management beyond project selection techniques: Understanding the role of structural alignment. International Journal of Project Management, 33(1), 126-139. https://doi.org/10.1016/j.ijproman.2014.03.002

Kettunen, J., \& Salo, A. (2017). Estimation of downside risks in project portfolio selection. Production and Operations Management, 26(10), 1839-1853. https://doi.org/doi:10.1111/poms.12727

Khalili-Damghani, K., \& Sadi-Nezhad, S. (2013a). Strategic framework for sustainable project portfolio selection and evaluation. International Journal of Sustainable Strategic Management, 4(1), 66-82. https://doi.org/10.1504/IJSSM.2013.056391

Khalili-Damghani, K., \& Tavana, M. (2014). A comprehensive framework for sustainable project portfolio selection based on structural equation modeling. Project Management Journal, 45(2), 83-97. https://doi.org/10.1002/pmj.21404 
Khalili-Damghani, K., Sadi-Nezhad, S., Lotfi, F. H., \& Tavana, M. (2013). A hybrid fuzzy rule-based multi-criteria framework for sustainable project portfolio selection. Information Sciences, 220, 442462. https://doi.org/10.1016/j.ins.2012.07.024

Khalili-Damghani, K., \& Sadi-Nezhad, S. (2013b). A hybrid fuzzy multiple criteria group decision making approach for sustainable project selection. Applied Soft Computing, 13(1), 339-352.

https://doi.org/10.1016/j.asoc.2012.07.030

Killen, C. P., \& Hunt, R. A. (2013). Robust project portfolio management: capability evolution and maturity. International Journal of Managing Projects in Business, 6(1), 131-151. https://doi.org/10.1108/17538371311291062

Koppinen, T., \& Rosqvist, T. (2010). Dynamic project portfolio selection in infrastructure sector. In Definitions, concepts and scope of engineering asset management (pp. 311-326). London: Springer. https://doi.org/10.1007/978-1-84996-178-3_16

Li, F., Cao, R., Li, S., Guo, C., \& Zhao, X. (2012, July). Parameterized model and approach for constrained project portfolio optimization. In 2012 IEEE International Conference on Service Operations and Logistics, and Informatics (pp. 462-467). IEEE. https://doi.org/10.1109/SOLI.2012.6273581

Li, L., Li, J., Qin, Q., \& Cheng, S. (2014). Fuzzy chance-constrained project portfolio selection model based on credibility theory. In Foundations of intelligent systems (pp. 731-743). Berlin, Heidelberg: Springer. https://doi.org/10.1007/978-3-642-54924-3_69

Li, X., Fang, S. C., Guo, X., Deng, Z., \& Qi, J. (2016). An extended model for project portfolio selection with project divisibility and interdependency. Journal of Systems Science and Systems Engineering, 25(1), 119-138. https://doi.org/10.1007/s11518-015-5281-1

Li, X., Fang, S. C., Tian, Y., \& Guo, X. (2015). Expanded model of the project portfolio selection problem with divisibility, time profile factors and cardinality constraints. Journal of the Operational Research Society, 66(7), 1132-1139. https://doi.org/10.1057/jors.2014.75

Li, X., Wang, Y., Yan, Q., \& Zhao, X. (2018). Uncertain mean-variance model for dynamic project portfolio selection problem with divisibility. Fuzzy Optimization and Decision Making, 18(1), 37-56. https://doi.org/10.1007/s10700-018-9283-6

Li, X., Zhong, Z., Zhang, Y., \& Wang, Y. (2017). Uncertain mean-variance model for project portfolio selection problem with divisibility. Journal of Intelligent \& Fuzzy Systems, 32(6), 4513-4522. https://doi.org/10.3233/JIFS-169215

Lifshits, A. A., \& Avdoshin, S. M. (2016). Algorithms for project portfolio selection based on fuzzy multi-objective model. In Emerging trends in information systems (pp. 65-77). Springer International Publishing. https://doi.org/10.1007/978-3-319-23929-3_6

Liu, B. (2007). Uncertainty theory. In Uncertainty theory (pp. 205-234). Berlin, Heidelberg: Springer. https://doi.org/10.1007/978-3-540-73165-8_5

Liu, Y., \& Liu, Y. K. (2017). Distributionally robust fuzzy project portfolio optimization problem with interactive returns. Applied Soft Computing, 56, 655-668. https://doi.org/10.1016/j.asoc.2016.09.022

Lukovac, V., Pamučar, D., Popović, M., \& Đorović, B. (2017). Portfolio model for analyzing human resources: An approach based on neuro-fuzzy modeling and the simulated annealing algorithm. Expert Systems with Applications, 90, 318-331. https://doi.org/10.1016/j.eswa.2017.08.034

Martínez-Vega, D. A., Cruz-Reyes, L., Gomez-Santillan, C., Rangel-Valdez, N., Rivera, G., \& Santiago, A. (2018). Modeling and project portfolio selection problem enriched with dynamic allocation of resources. In Fuzzy logic augmentation of neural and optimization algorithms: theoretical aspects and real applications (pp. 365-378). Cham: Springer. https://doi.org/10.1007/978-3-319-71008-2_26

Martins, C. L., López, H. M. L., de Almeida, A. T., Almeida, J. A., \& Bortoluzzi, M. B. D. O. (2017). An MCDM project portfolio web-based DSS for sustainable strategic decision making in an electricity company. Industrial Management \& Data Systems, 117(7), 1362-1375.

https://doi.org/10.1108/IMDS-09-2016-0412 
Mavrotas, G., \& Pechak, O. (2013a). Combining mathematical programming and Monte Carlo simulation to deal with uncertainty in energy project portfolio selection. In Assessment and simulation tools for sustainable energy systems (pp. 333-356). London: Springer.

https://doi.org/10.1007/978-1-4471-5143-2_16

Mavrotas, G., \& Pechak, O. (2013b). The trichotomic approach for dealing with uncertainty in project portfolio selection: combining MCDA, mathematical programming and Monte Carlo simulation. International Journal of Multicriteria Decision Making, 3(1), 79-96. https://doi.org/10.1504/IJMCDM.2013.052474

Mendel, J. M., John, R. I., \& Liu, F. (2006). Interval type-2 fuzzy logic systems made simple. IEEE Transactions on Fuzzy Systems, 14(6), 808-821. https://doi.org/10.1109/TFUZZ.2006.879986

Mira, C., Feijão, P., Souza, M. A., Moura, A., Meidanis, J., Lima, G., Bossolan, R. P., \& Freitas, İ. T. (2013, July). A project portfolio selection decision support system. In 2013 10th International Conference on Service Systems and Service Management (pp. 725-730). IEEE. https://doi.org/10.1109/ICSSSM.2013.6602536

Mira, C., Feijão, P., Souza, M. A., Moura, A., Meidanis, J., Lima, G., Schmitz, R., Bossolan, R. P., \& Freitas, I. T. (2012, December). A GRASP-based heuristic for the project portfolio selection problem. In 2012 IEEE 15th International Conference on Computational Science and Engineering (pp. 36-41). https://doi.org/10.1109/ICCSE.2012.102

Mohagheghi, V., \& Mousavi, S. M. (2019). A new framework for high-technology project evaluation and project portfolio selection based on Pythagorean fuzzy WASPAS, MOORA and mathematical modeling. Iranian Journal of Fuzzy Systems, 16(6), 89-106. https://doi.org/10.22111/ijfs.2019.5022

Mohagheghi, V., Mousavi, S. M., \& Siadat, A. (2015a). A new approach in considering vagueness and lack of knowledge for selecting sustainable portfolio of production projects. In IEEE International Conference on Industrial Engineering and Engineering Management (IEEM) (pp. 1732-1736). https://doi.org/10.1109/IEEM.2015.7385944

Mohagheghi, V., Mousavi, S. M., \& Vahdani, B. (2015b). A new optimization model for project portfolio selection under interval-valued fuzzy environment. Arabian Journal for Science and Engineering, 40(11), 3351-3361. https://doi.org/10.1007/s13369-015-1779-6

Mohagheghi, V., Mousavi, S. M., \& Vahdani, B. (2016). A new multi-objective optimization approach for sustainable project portfolio selection: a realworld application under interval-valued fuzzy environment. Iranian Journal of Fuzzy Systems, 13(6), 41-68. https://doi.org/10.22111/ijfs.2016.2821

Mohagheghi, V., Mousavi, S. M., Aghamohagheghi, M., \& Vahdani, B. (2017a). A new approach of multi-criteria analysis for the evaluation and selection of sustainable transport investment projects under uncertainty: A case study. International Journal of Computational Intelligence Systems, 10, 605-626. https://doi.org/10.2991/ijcis.2017.10.1.41

Mohagheghi, V., Mousavi, S. M., Vahdani, B., \& Shahriari, M. R. (2017b). R\&D project evaluation and project portfolio selection by a new interval type-2 fuzzy optimization approach. Neural Computing and Applications, 28(12), 3869-3888. https://doi.org/10.1007/s00521-016-2262-3

Mohagheghi, V., Mousavi, S. M., Vahdani, B., \& Siadat, A. (2017c). A mathematical modeling approach for high and new technology-project portfolio selection under uncertain environments. Journal of Intelligent and Fuzzy Systems, 32, 4069-4079. https://doi.org/10.3233/JIFS-152510

Mousavi, S. M., Jolai, F., \& Tavakkoli-Moghaddam, R. (2013). A fuzzy stochastic multi-attribute group decision-making approach for selection problems. Group Decision and Negotiation, 22(2), 207-233. https://doi.org/10.1007/s10726-011-9259-1

Mousavi, S. M., Tavakkoli-Moghaddam, R., Azaron, A., Mojtahedi, S. M. H., \& Hashemi, H. (2011a). Risk assessment for highway projects using jackknife technique. Expert Systems with Applications, 38, 5514-5524. https://doi.org/10.1016/j.eswa.2010.10.085

Mousavi, S. M., Tavakkoli-Moghaddam, R., Hashemi, H., \& Mojtahedi, S. M. H. (2011b). A novel approach based on non-parametric resampling with the interval analysis for large engineering project risks. Safety Science, 49, 1340-1348. https://doi.org/10.1016/j.ssci.2011.05.004 
Mousavi, S. M., Vahdani, B., Hashemi, H., \& Ebrahimnejad, S. (2015). An artificial intelligence modelbased locally linear neuro-fuzzy for construction project selection. Journal of Multiple-Valued Logic \& Soft Computing, 25(6), 589-604. Retrieved from https://www.oldcitypublishing.com/journals/ mvlsc-home/mvlsc-issue-contents/mvlsc-volume-25-number-6-2015/

Naderi, B. (2013). The project portfolio selection and scheduling problem: mathematical model and algorithms. Journal of Optimization in Industrial Engineering, 6(13), 65-72.

Nikkhahnasab, M., \& Najafi, A. A. (2013). Project portfolio selection with the maximization of net present value. Journal of Optimization in Industrial Engineering, 6(12), 85-92.

Nowak, M. (2013). Project portfolio selection using interactive approach. Procedia Engineering, 57, 814-822. https://doi.org/10.1016/j.proeng.2013.04.103

Olsson, R. (2008). Risk management in a multi-project environment: An approach to manage portfolio risks. International Journal of Quality \& Reliability Management, 25(1), 60-71. https://doi.org/10.1108/02656710810843586

Olundh, G., \& Ritzen, S. (2004, October). Making an ecodesign choice in project portfolio selection. In IEEE 2004 Engineering Management Conference (Vol. 3, pp. 913-917).

Panadero, J., Doering, J., Kizys, R., Juan, A. A., \& Fito, A. (2018). A variable neighborhood search simheuristic for project portfolio selection under uncertainty. Journal of Heuristics, 1-23. https://doi.org/10.1007/s10732-018-9367-z

Perez, F., \& Gomez, T. (2016). Multiobjective project portfolio selection with fuzzy constraints. Annals of Operations Research, 245(1-2), 7-29. https://doi.org/10.1007/s10479-014-1556-Z

Pérez, F., Gómez, T., Caballero, R., \& Liern, V. (2018). Project portfolio selection and planning with fuzzy constraints. Technological Forecasting and Social Change, 131, 117-129. https://doi.org/10.1016/j.techfore.2017.07.012

Project Management Institute. (2008). The standard for portfolio management (2nd ed.). Project Management Institute, Newtown Square, PA.

Qin, Q., Li, J., \& Li, L. (2014, May). A fuzzy two-stage project portfolio selection model addressing financial and non-financial factors. In The 26th Chinese Control and Decision Conference (2014 CCDC) (pp. 1349-1353). IEEE. https://doi.org/10.1109/CCDC.2014.6852376

Rabbani, M., Najjarbashi, A., \& Joudi, M. (2013). A new multi-objective model for R\&D project portfolio selection considering potential repetitive projects and sanction impacts. International Journal of Strategic Decision Sciences (IJSDS), 4(4), 41-54. https://doi.org/10.4018/ijsds.2013100103

Riddell, S., \& Wallace, W. A. (2007). The use of fuzzy logic and expert judgment in the R\&D project portfolio selection process. In PICMET '07 - 2007 Portland International Center for Management of Engineering and Technology (pp. 1228-1238). IEEE. https://doi.org/10.1109/PICMET.2007.4349446

Riddell, S., \& Wallace, W. A. (2011). The use of fuzzy logic and expert judgment in the R\&D project portfolio selection process. International Journal of Technology Management, 53(2-4), 238-256. https://doi.org/10.1504/IJTM.2011.038592

Rivera, G., Gómez, C. G., Fernández, E. R., Cruz, L., Castillo, O., \& Bastiani, S. S. (2013). Handling of synergy into an algorithm for project portfolio selection. In Recent Advances on Hybrid Intelligent Systems (pp. 417-430). Berlin, Heidelberg: Springer. https://doi.org/10.1007/978-3-642-33021-6_33

Roland, J., Figueira, J. R., \& De Smet, Y. (2016). Finding compromise solutions in project portfolio selection with multiple experts by inverse optimization. Computers \& Operations Research, 66, 12 19. https://doi.org/10.1016/j.cor.2015.07.006

Schaeffer, S. E., \& Cruz-Reyes, L. (2016). Static R\&D project portfolio selection in public organizations. Decision Support Systems, 84, 53-63. https://doi.org/10.1016/j.dss.2016.01.006

Schniederjans, M. J., \& Santhanam, R. (1993). A multi-objective constrained resource information system project selection method. European Journal of Operational Research, 70(2), 244-253. https://doi.org/10.1016/0377-2217(93)90042-L 
Sefair, J. A., Méndez, C. Y., Babat, O., Medaglia, A. L., \& Zuluaga, L. F. (2017). Linear solution schemes for Mean-SemiVariance Project portfolio selection problems: An application in the oil and gas industry. Omega, 68, 39-48. https://doi.org/10.1016/j.omega.2016.05.007

Shariatmadari, M., Nahavandi, N., Zegordi, S. H., \& Sobhiyah, M. H. (2017). Integrated resource management for simultaneous project selection and scheduling. Computers \& Industrial Engineering, 109, 39-47. https://doi.org/10.1016/j.cie.2017.04.003

Shou, Y. Y., \& Huang, Y. L. (2010). Combinatorial auction algorithm for project portfolio selection and scheduling to maximize the net present value. Journal of Zhejiang University SCIENCE C, 11(7), 562-574. https://doi.org/10.1631/jzus.C0910479

Smarandache, F. (2005). Neutrosophic set-a generalization of the intuitionistic fuzzy set. International Journal of Pure and Applied Mathematics, 24(3), 287.

Stummer, C., Kiesling, E., \& Gutjahr, W. J. (2009). A multicriteria decision support system for competence-driven project portfolio selection. International Journal of Information Technology \& Decision Making, 8(02), 379-401. https://doi.org/10.1142/S0219622009003429

Tang, B. J., Zhou, H. L., \& Cao, H. (2017). Selection of overseas oil and gas projects under low oil price. Journal of Petroleum Science and Engineering, 156, 160-166.

https://doi.org/10.1016/j.petrol.2017.05.022

Tavana, M., Keramatpour, M., Santos-Arteaga, F. J., \& Ghorbaniane, E. (2015). A fuzzy hybrid project portfolio selection method using data envelopment analysis, TOPSIS and integer programming. Expert Systems with Applications, 42(22), 8432-8444. https://doi.org/10.1016/j.eswa.2015.06.057

Tavana, M., Shiraz, R. K., \& Di Caprio, D. (2019). A chance-constrained portfolio selection model with random-rough variables. Neural Computing and Applications, 31(S2), 931-945.

https://doi.org/10.1007/s00521-017-3014-8

Teller, J., \& Kock, A. (2013). An empirical investigation on how portfolio risk management influences project portfolio success. International Journal of Project Management, 31(6), 817-829. https://doi.org/10.1016/j.ijproman.2012.11.012

Tofighian, A. A., Moezzi, H., Barfuei, M. K., \& Shafiee, M. (2018). Multi-period project portfolio selection under risk considerations and stochastic income. Journal of Industrial Engineering International, 14(3), 571-584. https://doi.org/10.1007/s40092-017-0242-6

Urli, B., \& Terrien, F. (2010). Project portfolio selection model, a realistic approach. International Transactions in Operational Research, 17(6), 809-826. https://doi.org/10.1111/j.1475-3995.2010.00762.x

Wang, B., \& Song, Y. (2016). Reinvestment strategy-based project portfolio selection and scheduling with time-dependent budget limit considering time value of capital. In Proceedings of the 2015 International Conference on Electrical and Information Technologies for Rail Transportation (pp. 373-381). Berlin, Heidelberg: Springer. https://doi.org/10.1007/978-3-662-49370-0_39

Wang, C. S., \& Chen, W. (2011, November). A fuzzy model for R\&D project portfolio selection. In 2011 International Conference on Information Management, Innovation Management and Industrial Engineering (Vol. 1, pp. 100-104). IEEE. https://doi.org/10.1109/ICIII.2011.30

Wang, C., \& Shou, Y. (2011, December). Application of real options in project portfolio selection. In 2011 IEEE International Conference on Industrial Engineering and Engineering Management (pp. 848-853). https://doi.org/10.1109/IEEM.2011.6118036

Wen, J. (2010, November). The strategy-oriented project portfolio selection and management. In IEEE 2010 International Conference on E-Product E-Service and E-Entertainment (pp. 1-4). https://doi.org/10.1109/ICEEE.2010.5660739

Wu, Y., Xu, C., Ke, Y., Chen, K., \& Sun, X. (2018). An intuitionistic fuzzy multi-criteria framework for large-scale rooftop PV project portfolio selection: Case study in Zhejiang, China. Energy, 143, 295-309. https://doi.org/10.1016/j.energy.2017.10.105 
Xu, W., Liu, G., Li, H., \& Luo, W. (2017). A study on project portfolio models with skewness risk and staffing. International Journal of Fuzzy Systems, 19(6), 2033-2047. https://doi.org/10.1007/s40815-017-0295-0

Yager, R. R. (2013). Pythagorean membership grades in multicriteria decision making. IEEE Transactions on Fuzzy Systems, 22(4), 958-965. https://doi.org/10.1109/TFUZZ.2013.2278989

Yan, S., \& Ji, X. (2018). Portfolio selection model of oil projects under uncertain environment. Soft Computing, 22(17), 5725-5734. https://doi.org/10.1007/s00500-017-2619-2

Yang, F., Song, S., Huang, W., \& Xia, Q. (2015). SMAA-PO: project portfolio optimization problems based on stochastic multicriteria acceptability analysis. Annals of Operations Research, 233(1), 535 547. https://doi.org/10.1007/s10479-014-1583-9

Yang, Y., \& John, R. (2012). Grey sets and greyness. Information Sciences, 185(1), 249-264. https://doi.org/10.1016/j.ins.2011.09.029

Yu, L., Wang, S., Wen, F., \& Lai, K. K. (2012). Genetic algorithm-based multi-criteria project portfolio selection. Annals of Operations Research, 197(1), 71-86. https://doi.org/10.1007/s10479-010-0819-6

Zaras, K., Marin, J. C., \& Boudreau-Trude, B. (2012). Dominance-based rough set approach in selection of portfolio of sustainable development projects. American Journal of Operations Research, 2(04), 502-508. https://doi.org/10.4236/ajor.2012.24059

Zavadskas, E. K., Bausys, R., Kaklauskas, A., Ubarte, I., Kuzminske, A., \& Gudiene, N. (2017a). Sustainable market valuation of buildings by the single-valued neutrosophic MAMVA method. Applied Soft Computing, 57, 74-87. https://doi.org/10.1016/j.asoc.2017.03.040

Zavadskas, E. K., Turskis, Z., Tamošaitiené, J., \& Marina, V. (2008). Multicriteria selection of project managers by applying grey criteria. Technological and Economic Development of Economy, 14(4), 462-477. https://doi.org/10.3846/1392-8619.2008.14.462-477

Zavadskas, E. K., Turskis, Z., Vilutienè, T., \& Lepkova, N. (2017b). Integrated group fuzzy multi-criteria model: Case of facilities management strategy selection. Expert Systems with Applications, 82, 317331. https://doi.org/10.1016/j.eswa.2017.03.072

Zavadskas, E. K., Vilutiene, T., Turskis, Z., \& Šaparauskas, J. (2014). Multi-criteria analysis of Projects' performance in construction. Archives of Civil and Mechanical Engineering, 14(1), 114-121. https://doi.org/10.1016/j.acme.2013.07.006

Zhang, W. G., Mei, Q., Lu, Q., \& Xiao, W. L. (2011). Evaluating methods of investment project and optimizing models of portfolio selection in fuzzy uncertainty. Computers \& Industrial Engineering, 61(3), 721-728. https://doi.org/10.1016/j.cie.2011.05.003

Zhao, W., Wu, Q., \& Wen, X. (2018, November). Research on the evaluation method of green construction project based on grey entropy correlation. In IOP Conference Series: Materials Science and Engineering (Vol. 439, No. 3, p. 032052). IOP Publishing. https://doi.org/10.1088/1757-899X/439/3/032052

Zhou, D., Huang, H., Teng, C., \& Zhao, P. (2012). Project selection of robust portfolio models with incomplete information. Journal of Finance and Investment Analysis, 1(2), 157-199.

Zhou, X., Wang, L., Liao, H., Wang, S., Lev, B., \& Fujita, H. (2019). A prospect theory-based group decision approach considering consensus for portfolio selection with hesitant fuzzy information. Knowledge-Based Systems, 168, 28-38. https://doi.org/10.1016/j.knosys.2018.12.029

Zhu, D., \& Wang, X. (2012). A petroleum R\&D project portfolio investment selection model with project interactions under uncertainty. Journal of Petroleum Science Research, 44-50. Retrieved from http://www.airitilibrary.com/Publication/alDetailedMesh?docid=P20150604011201210-201508180020-201508180020-44-50

Zolfaghari, S., \& Mousavi, S. M. (2018). Construction-project risk assessment by a new decision model based on De-Novo multi-approaches analysis and hesitant fuzzy sets under uncertainty. Journal of Intelligent and Fuzzy Systems, 35, 639-649. https://doi.org/10.3233/JIFS-162013 